\title{
Globalization and Modernity
}

\author{
Jason L. Powell \\ Faculty of Health \& Life Sciences, Coventry University, Priory Street, CV1 5FB, \\ Coventry, United Kingdom \\ E-mail address: jasonpwll3@gmail.com
}

\begin{abstract}
As we move into the global century, several aspects of social and economic life are changing and post-industrial shifts are unparalleled by virtue of the interconnectedness that brings together the corners of the globe. New technologies, new economic relationships, new social processes, and new political developments are all characteristics of globalization (Hudson and Lowe, 2004: 22) in a post-industrial age featured by information, innovation, finance and services. As the world has contracted, people's quality of life has changed regardless of where they live. In fact, the propagation of free market mindsets in emerging economies has created collective network connections with considerable good but pervasive inequalities as well. A fundamental aim of this book is to argue that these changes are part of a economic transition to post-industrialism associated with risks and inequalities that shape human experience in the midst of a formidable global financial climate. There is an obvious tension with this. On the one hand, life expectancy, health statuses and per capital incomes are at an all-time high and many feudal practices have been relegated to the past (Phillipson, 2006). On the other hand, vast numbers of people struggle with poverty and significant pockets of poverty portend more than lack of income. Those living on the bottom of the socio-economic ladder labor under the burden of avoidable, lifestyle diseases, hunger and related maladies, not to mention myriad social risks (Turner, 2008). Those on the upper reaches of the same ladder garner disproportionate shares of the resources and are able to support comfortable lifestyles.
\end{abstract}

Keywords: globalization; modernity; power; nation states; resources

\section{Reviewer:}

Dr Jamie Halsall, University of Huddersfield, UK 
Table of Contents

Abstract

Chapter one: Introduction

Chapter two: Globalization and Economics

Chapter three: Globalization and Modernity

Bibliography 


\section{CHAPTER ONE: INTRODUCTION}

Globalization has a rich history associated with the emergence of modernity. Indeed, the rise of modernity has been defined by a number of historical processes including the Atlantic Slave Trade and attendant institutions of slavery, and European colonization of Africa Asia and Latin America. The idea of modernity evokes the development of capitalism and industrialisation, as well as the establishment of nation states and the growth of regional disparities in the World system. The period has witnessed a host of social and cultural transformations. Significantly, racial categories emerged during this epoch as two fundamental axes along which people were exploited and societies stratified.

A hallmark of modernity is the expansion of Europe and the establishment of Euro/American cultural hegemony throughout the world. Nowhere is this more profound than in the production of sociological knowledge about human behaviour. As a result, the theoretical interests and concerns of Enlightenment philosophers such as Kant and Rousseau coupled with historical social theories Marx, Durkheim and Weber have dominated intellectual thought.

Indeed, Marx, Weber, and Durkheim have provided theoretical models which capture many elements of the global world: capitalism; religion and rationalisation; and division of labour. Their models were developed in nineteenth and early twentieth century Europe, and were based primarily on their study of European society and European thought. Marx, Weber, and Durkheim considered their approaches universal in the sense of developing an understanding and analysis of all societies at all times. They wrote in a Europe that dominated much of the rest of the world politically and economically, and the authors of European social thought of this period generally considered their analyses universal. For example, Weber's Protestant Ethic argument was designed to show why Christianity, continuing certain patterns of ancient Judaism, gave rise to the dynamism of modern capitalism; whereas the omitted civilizations of Confucianism, Buddhism, Hinduism and Islam did not.

Marx, Durkheim and Weber have been accused of being eurocentric. This is the practice, conscious or otherwise, of placing emphasis on European and, generally western theories and ideas at the expense of those of other cultures.

Implicit in this definition is the assumption that Western concepts are fundamentally different from those in other cultures or civilizations. A somehow contradictory but equally important implication is the assumption that Western concepts are universal; including individualism, human rights, secular authority and law, and the separation of religion and state. For Blaut (2000) the are four principal ideological claims that underpin Eurocentric explanations of the power of the West:

1. Religion: Europeans (Christians) worship the true God and he guides them forward through history.

2. Race: White people have an inherited superiority over the people of other races.

3. Environment: The natural environment of Europe is superior to all others.

4. Culture: Europeans, long ago, invented western culture that is progressive and innovative.

One effect of this definition of Eurocentrism is the racialisation of knowledge: Europe is represented as the source of knowledge and Europeans as knowers. Indeed, male gender privilege as an essential part of European ethos is enshrined in the culture of modernity. 


\section{Occidental Modernity: The Great Divide - The West v The Rest}

According to Mann (1986) the approach to understanding western modernity as a social/political/economic phenomenon may be entitled the 'Great Divide' perspective to theoretical analysis. This approach sees history in terms of a single great divide between the modern, Western, industrial world and that of the 'rest' (Worsley 1987). Not only that, the power of the nation states to wield their power over non-western states saw its fruition with the rise of colonialism and slavery. Indeed, Gilroy (1987) asks if historically, the 'Enlightenment' and 'Modernity' equates with narratives of 'progress', how does this fit with the historical and contemporary economic, cultural and racist exploitation of African countries? Similarly, in recent times, Giddens (1993) points out that the economic power of multi-national corporations (General Motors) outstrips the financial revenue of many third world countries; meaning economic dependence of third world countries has become contingent on non-democratic organisations such as corporations.

Giddens (1991) suggests that the dynamism of the modern world is linked with modernity, that is, a social process that subsumes capitalism in a broader set of features. Globalisation is seen as having been made possible by what Giddens (1990) calls 'modernisation'. For him, there are four major aspects of 'late modernity': capitalism, industrialism, the surveillance capacities of the nation state and nationally based military power. These trends are identified as a Western phenomenon that subsequently illuminates the leading role of the 'West' in each of these aspects of what can be called 'globalisation'.

Capitalism has created a single world-wide division of labour and market for capital and commodities while industrialism in the $19^{\text {th }}$ and $20^{\text {th }}$ centuries formed the technological and organisation base for these trends. For example, modern communications advances, such as satellite delivery systems and computer technologies based on the microchip are unthinkable without a strong industrial base. Similarly, the rise of nation-states has encouraged the development of transnational political organisation designed to regulate conflicts between nation states. For example, the United Nations (UN) was founded by Western nation states to curtail conflict in the world order. Finally, there is the issue of military power in global affairs. This has been an important causal mechanism in securing resources and overcoming obstacles that threaten the dominance of Western globalisation (See Gulf War II, 2003-). This is also reflected in the colonisation process that from the $16^{\text {th }}$ century onwards acted as an arm of political and economic imperialism in South and East Asia (Mann 1986).

\section{The Eurocentricism of the 'Great Divide' thesis}

It is the 'West' rather than the global system as a whole that solves or worsens population subsistence crises. According to Roland Robertson (1992) there is a very biased perspective which suggests that by adopting Western economic and social institutions other non-Western nations and regions can only advance. This implies that the 'rest' in some way are not as proficient as the 'west'. According to Phillipson and Powell (2004) 'the West' is very much a term for the 'club' of the economically and politically successful. The danger and risk of enforcing western ideals on diverse cultures is a 'straight jacketing' of western culture on nonwestern cultures. Featherstone (1995) makes the point that the problem of western culture idealises a 'universal' consumer dream in which everyone on the globe can become a part of. The dark side of this is that in order for production of consumer goods to materialise, many immigrants from third world countries have been financially exploited for their labour. 
Further, Hall (1992) perceives modernity as the dominance of Western economic and cultural interests over the 'rest' of the world. This dominance means the perpetuation of inequality between rich and poor countries and regions. Wallerstein (1980) has described this as the operation of the 'world capitalist order' or to mis-paraphrase former US President George Bush it is a process of 'the new world disorder'.

The problem here is not only the perpetuation of gross inequalities, but also what has been referred to as the 'Coca-Colonization' (Vincent 1999) of the world, whereby Third World populations are incorporated into the western economy as passive consumers of standardised products and nothing more. Perhaps we need to ask the question if modernity is synonymous with the history and contemporary power of the 'west' against the 'rest'? This book assesses the global issues that affect power across the globe: neo-liberalism and economics. 


\section{CHAPTER TWO: GLOBALIZATION AND ECONOMICS}

This chapter explicates how transformations in globalization are of historical scale, how they play out in terms of risks and inequalities shaping human experience, and how they have changed social welfare and public policy making worldwide.

After presenting facts of inequality and such consequences as planetary poverty and gender stratification, it highlights the reformulation of economic power associated with burgeoning free-market economies and accompanying diffusion of instrumental rationality, standardization, commoditization, or secularism. In contrast with the economic downturn and global softening of labor markets which cry for greater social protection, the welfare state of the last century has been replaced by a competitive state of the 21 st century, as a "non-sovereign power" mindful of its global positioning but less powerful in shaping daily life among social forces including the role of NGOs. Indicating a lag between transnational developments and the way analysts think of social policies, the book asserts that nation-states nonetheless serve important administrative functions in a world dominated by transnational corporate interests.

With few options and having to make hard choices, welfare provision has seen trends toward commodification of social services etc. while globalization is affecting social contracts as well. In considering all the challenges to justice and governance, the authors argue that social welfare needs to be redefined and extended while market economy must be guided by moral principles that embody fundamental human values.

\section{Introduction}

As we move into what can be called the "global century", many aspects of social and economic life are changing and post-industrial shifts are unparalleled by virtue of the interconnectedness that brings together the far corners of the globe.

New technologies, new economic relationships, new social processes, and new political developments are all characteristics of globalization (Hudson and Lowe, 2004: 22) in a postindustrial age featured by information, innovation, finance, and services. As the world has contracted, people's quality of life has changed regardless of where they live. In fact, the propagation of free market mindsets in emerging economies has created collective network connections with considerable good but pervasive inequalities as well.

A principal aim of this book is to explicate how these changes are of historical scale, how they are part of what post-industrial welfare is all about, and how they play out in terms of risks and inequalities shaping human experience. There is a tension with this. On the one hand, life expectancy, health statuses and per capital incomes are at an all-time high and many feudal practices have been relegated to the past (Phillipson, 2006). On the other hand, vast numbers of people struggle with poverty and significant pockets of poverty portend more than lack of income.

Those living on the bottom of the socio-economic ladder labor under the burden of avoidable, lifestyle diseases, hunger and related maladies, not to mention myriad social risks (Turner, 2008). Those on the upper reaches of the same ladder garner disproportionate shares of the resources and are able to support comfortable lifestyles (Esping-Anderson, 1990). 


\section{Global Poverty and Inequality}

Around the globe there are bona fide challenges facing nation-states as they attempt to adapt to the impact of modifications in morbidity, mortality, and need gradients among diverse segments of their populations. In the face of rapid demographic transformations resulting in fewer casualties from acute diseases, aging of populations, and tumultuous economies, there are widening disparities between the "haves" and the "have nots" and considerable quality-oflife inequalities within and between populations. In developing countries, China being one of the most striking cases in point but with parallels in a number of other developing countries the differential in per capital incomes of urban and rural people is at least a factor of three with virtually no top quartile wage earners residing in rural areas (Powell and Cook, 2010). Not surprisingly, there is a tangible rural to urban migration for economic gain, thereby creating even greater disparities as those left behind barely eke out subsistence livings.

It is impossible to overstate the risks of planetary poverty. More than 2.5 billion of the planet's population live on less than US $\$ 2$ a day and nearly a billion still have less than US\$1 daily (Chen \& Ravallion, 2007). As might be apparent, in this day and age poverty creates conditions in which rationality is redefined, nation-states struggle to control circumstances, not to mention criminality, low birth weights are ubiquitous, ill-health a fact of life, illiteracy rampant, malnutrition commonplace, environmental degradation seen as the cost of doing business, and notions of social justice are brought face-to-face with priorities said to have greater standing (Beck, 1999). Focusing on the extent of the disparities for just a moment: not only is there asymmetry but real immiseration as well -- only about five percent of the world's income is earned by the poorest $40 \%$ of its people (Estes, Biggs and Phillipson, 2003).

The chasm between rich and poor is becoming even steeper. According to the $12^{\text {th }}$ Annual World Wealth Report (2008), the wealth of people around the world with more than US\$1 million in assets grew faster in 2007 than the world's economy. The world's economy exhibited a $5 \%$ gain in 2007; compared with a growth rate of over $9 \%$ among those with at least US\$1 million in assets. Furthermore, the average wealth of these high net worth individuals (HNWIs) climbed to over US\$ 4 million, exclusive of their residence. Interestingly, the greatest growth among HNWIs occurred in Eastern Europe, Latin America and Asia led by Brazil, Russia, India and China. When the "mass affluent" population (those with less than US\$ 1 million but with substantial assets nonetheless) is added to the picture, the result is that the richest 20 percent of the world's population controls more than $75 \%$ of its wealth. In the past few decades there has been some astonishing gains among a relatively small percentage of the world's population (approximately 10 million out of 6.7 billion people can be classified as HNWIs) who are tapped into robust gains and wealth generation strategies (Annual World Wealth Report, 2008). As should be apparent, the ascendancy of those forces concentrating high net worth wealth and capital accumulation among a narrow upper-crust is also capable of producing abject poverty among other segments of the population (Arias and Logan, 2002:197; Jessop, 2002). While the richest 1 percent of wealthy outliers are benefiting from speculation and the deregulation of commerce and free trade, those on the other end of the economic ladder are gaining little, if at all as the wealth gap widens.

Some estimates conservatively place the gap between the richest and poorest nations at an all time high of more than 50 to 1 (Clark, 2007). Even with the stalling of mature economies, the gulf between the most advantaged and the most disadvantaged in developed countries is no less dramatic; factor in the impact of gender, ethnicity or other social impediments and the complexity intensifies as formidable inequalities shape well-being (Powell and Cook, 2010). 
The disparities play out in a number of ways, extending well beyond vital income differentials to quality of life issues, education, structured dependencies or social exclusions resulting from policy decisions (Townsend, 2007). Navarro (2007) and others add their voice to Townsend's assertion by noting that escalating differentials can be attributed in no small part to interventionist strategies adopted and endorsed by national governments. Not surprisingly, as a consequence of the richest segments of the population having far greater assets and control over their lives, they feel they have more in common with their counterparts in other regions than they do with their less affluent opposite number in their own regions (Hoogvelt, 1997).

These trends are becoming increasingly vivid and no government is evading the prospect of having to reshuffle what they provide their citizens. Cross-cultural comparisons are extraordinarily valuable in helping lay out causal connections and for double-checking inferences. For example, the Organization for Economic Co-operation and Development (OECD) has a reliable cross-national comparative database of indicators of social policy expenditures in 30 member nations and their state sponsored social welfare provisions entitled Social Expenditures (SocX) in the period 1980-2003. It covers public expenditures for typical forms of welfare including old age, survivors, incapacity-related benefits, health, family, active labor market programs, unemployment, housing, and other social policy areas (education excepted).

Shalev (2007) points out that if health and pension benefits are combined as a share of GDP countries like Sweden rank at the top by devoting some $14 \%$ of its GDP to health and pension protections. Data for the period 1980-2001, the latest available on the OCED web-site, suggests that Germany expends about $8 \%$ and the United States and Japan about $4 \%$. Overall, however, the English speaking countries are among the most conservative spenders for health and old-age provisions, while Japan is a high spender when all provisions are considered.

\section{Globalization and Reformulation of economic power}

The proliferation of adjuvant ideologies evolving out of burgeoning free-market economies along with an accompanying diffusion of instrumental rationality, standardization, commoditization, or secularism have become embedded in our thinking, challenging all other relational metrics of daily life. In the process, modes of interaction and standards of assessing relational status or personal worth are recast. In both developed and emerging economies the nature of work and the meaning of careers are also undergoing major reformulations. There is a global softening of labor markets linked to downsizing of local employment opportunities, redundancies, a spate of subcontracting arrangements, and an economic volatility abetted by technological innovations that chip away at employment security, wage or benefit packages bringing a degree of economic and existential uncertainty to greater numbers of people. Of course such changes are not distributed evenly across all forms of employment, further exacerbating inequalities.

It should also be stressed that adversity does not appear to strike women and men equally - and it is certainly reasonable to say that disadvantage begets disadvantage when downturns occur. Women are disproportionately among the most disadvantaged and with age even greater hardships accrue to them. Adding to the intricacies of these unparalleled changes is the velocity with which they are taking place and the fact that they are accompanied by a deepening division between those whose principal pursuits are in subsistence or service sector markets and their counterparts who are primarily involved in large-scale export, international sectors, or equity markets. Together these forces are bringing about a profound imbalance within and between 
populations as one group shares in the generation of wealth while the other becomes increasingly dependent and is being subordinated to decisions made in the other sector, by a cartel half a world away (Bauman, 1998).

Without suggesting or trying to make it sound as though national governments or their policies are anything less than all-encompassing in their reach, it is also the case that national governments no longer set their own course independently of economic currents sweeping around the globe, felt in every country and affecting virtually every policy a government might implement. This is not to say that states are mere minions of transnational interests but it is no longer the case that nation-state sovereignty can be taken-for-granted in the policy realm. Nor is it necessarily the case that state policies are as all-powerful as they once were in shaping daily life (Dallmayer, 2005; Fraser, 2005). As Evans and Cerny (2004) so cogently assert, the welfare state of the last century has been replaced by a competitive state of the $21^{\text {st }}$ century, always mindful of its global positioning (see also, Hudson \& Lowe, 2004).

Foucault (1978) coined the phrase "non-sovereign power" when he was discussing issues of bodily control. By drawing a nice analogy Yapa (2002:15) proposes that a parallel concept may provide insights into the vagaries of post-industrial public-sector decision making. To make sense of domestic versus international priorities and their effect on daily life, scholars would do well to come to terms with the notion of "non-sovereign power" as it applies to social justice, autonomy, monetary policies and capital mobility, and other forms of extra-national pressures emending local policies. We would assert that to date there has been a real lag between transnational developments and the way analysts think of social policies. Appadurai (2001) attributes the stumbling blocks in conceptualization to "...the disjunctures between various vectors characterizing this world-in-motion that produce fundamental problems of livelihood, equity, suffering, justice, and governance" (Appadurai, 2001: 6). In his characterization, proximate social issues have causes that are hardly local and call for non-parochial perspectives if they are to be addressed.

As Giddens maintains, one of the most significant impacts of globalization is that it has brought an "intensification of worldwide social relations which link distant localities in such a way that local happenings are shaped by events occurring many miles away and vice versa" (Giddens, 1990:64). As a consequence, few governments are eager to make decisions separately from their reliance on global enterprise; it is as though they are in a situation of shared sovereignty, having to negotiate between domestic, international, corporatist, and transnational interests (Esping-Andersen, 1990; Hill, 2006; Kennett, 2001; Navarro, 2007). NGOs such as the World Bank and the International Monetary Fund have also become architectural partners in local policy deliberations by sanctioning preferred welfare policies as a condition of their support of monetization (Deacon, Hulse, \& Stubbs, 1997; Dembele, 2007; Hart, 2002). Even so, nation-states nonetheless serve important administrative functions in a world dominated by transnational corporate interests and it is unlikely that governmental responsibilities are either going to be usurped or allowed to wither in light of their functionality (Hill, 2006; Navarro, 2007). It is not too far fetched to say that certain transnational interests see themselves as having universal jurisdiction, assertions of state autonomy notwithstanding.

With the spreading of these transformations has come a reshuffling of local priorities, with governmental emoluments directed or redirected to areas defined as having the greatest public importance and bringing the greatest returns. Of course the realities behind that assertion are deserving of close scrutiny as the policy process is unquestionably political and the state must mediate rival claims as it serves as the principal mechanism by which revenues are collected and resources distributed. Meanwhile, social entitlements, expenditures, and daily experience for people who may not fully grasp the raison d'être behind their situations reflect 
these same priorities. Hill (2006) suggests that social policy regimes are regularly structured to be consistent with other forms of social stratification within a country. To the extent there is a convergence in social welfare policies around the globe it might not be mere coincidence that social stratification and social class divisions are growing more pronounced in the face of globalization. In light of global economic flows, the salience and permeability of national borders, whether in Europe, the western hemisphere, or in the East are a different matter than they were even half a century ago (Kearney, 1995).

In terms of both economics and domestic social policies, the impact of international economic relations has recontoured the landscape, so to speak, all the way to the regionalization and appropriation of economic relations. What were once bold lines of demarcation are now dotted lines more suggestive of administrative spheres than jingoistic borders. In the global century, deregulated markets are tightly integrated with political and social transformations, affecting local circumstances and communality (Geetz, 1973). All in all, the globalizing influences of the early $21^{\text {st }}$ century are producing a distinctive era in social history linked to the emergence of transnational actors as well as economics and technologies that are helping fuel the shifts. Global economic change portends more than alterations in per capita income, the nature of financial products and currency markets, or the rapid circulation of goods, communication or technologies.

It is precursor to broad cultural and political shifts that challenge pre-contact arrangements, notions of social justice and solidarity, as well as local interaction patterns. In a post-modern world, globalization is creating interlocking dependencies linked to the ways in which priorities are ordained by transnational interests. As Chen and Turner (2006) point out in a discussion focused on the welfare of the elderly but equally applicable to all social welfare, the accrual of public benefits reflects the invisible hand of market forces, the invisible handshake of tradition, and the invisible foot of political decisions. Despite avowals about the secularity of modern life, economic-thinking, what might be termed spreadsheet logic, is accorded near theological status, its canons seen as universally applicable and providing appropriate precept for adjudicating what is considered fair and just. These tendencies are abetted by what is sometimes called the cyber infrastructure, or more simply, informatics, reinforcing these shifts and creating a digital divide separating those on either edge of the diffusion of innovations. Of course there is more to this technological transformation than the appearance of new ways to communicate, it has also paved the way to a post-fordist formulation that Castells (2000) labels network capitalism.

\section{Globalization and the Social Contract}

We do not mean to imply that globalization comes as a unified package; it is nonetheless true that major changes have resulted from an ability to move capital around as summarily as desired to gain leverage, possibly destabilizing local financial and labor-markets in the process. Real questions have emerged about the autonomy of nation-states and the balancing of altruistic social expenditures with economic participation on the world stage. The tensions between social protections and global corporate connections are contributing to what can aptly be called "social deficits" in which people are left to fend for themselves to the extent that they are able. In the face of inflation and related economic adversities, slashing social spending is routinely offered as a fitting resolution preferable to raising taxes for wealthy individuals or corporations (Mishra, 1999). The global span of information technologies and the advent of the global compass held by transnational corporations means they are able to shift extraction, 
manufacturing, fabrication and many service functions to whatever locale offers the most favorable economic returns, including tax structures. These and other consequences of globalization are fraught with new risks and ambiguities in daily experience and in the way matters of worth are defined; along with the many positive aspects that are undeniably part of the process associated with privatization.

In a synopsis of a few of the more evident effects of globalization, Navarro (2007) points to the privatization of services, public assets, and other public provisions in asymmetrical fashion; deregulation of labor and currency markets as well as other forms of commerce; free trade; escalation of an accompanying anti-interventionist rhetoric; encouragement of individualism and consumerism. A number of commentators have noted that a corollary of globalization results in an unprecedented pattern of social risk. As Townsend (2007) so elegantly points out, the globalization of the marketplace is changing the face of dependency. It is as though the configuration of risks has shifted from settling on just those poor, down and outers living along society's margins to those derailed by restructuring of labor markets, the dramatic spread of employment in service sector jobs, shifts in the types of career patterns that so characterized the $20^{\text {th }}$ century, and the role of informatics affecting employability of middleclass workers.

These risks are not grounded merely in the absence of resources but in an absence of personal autonomy and by people's position relative to others. Add to these factors the fact that as they wrestle with the issues, national and local governments are assailed from multiple fronts; pressed by transnational interests to provide open trade liberalization for private enterprise; and pressed by the growing need for social protections and labor policies to sustain the working populace and those whose lives have fallen through the proverbial social safety net. Ever more inclusive protections call for targeted expenditures at exactly the time when expenditures are hemmed-in by capacity to levy taxes of any type but especially progressive taxes and by powerful interested constituencies. The neoliberal globalizing drive has disenfranchised workers and their representatives in ways that have eroded their ability to bargain for benefits. Many commentators have noted that governments have generally adopted a laissez faire stance when for one reason or another they have chosen not to intervene in the disempowerment of the citizenry (Navarro, 2007).

As a facet of a much broader movement toward privatization, governmental social services are adopting a market-based management model and relying on non-governmental agencies (NGOs) to take up the slack. There is a wide array of subtypes and expenditure patterns associated with every form but an underlying logic in nearly all instances is a push toward commodification or cost-effectiveness of the programs (couched in terms of return on investment measured by market-driven stipulations), in contrast to their ability to genuinely affect lives. Policy recipients not likely to provide economic returns on governmental investments in them tend to be defined as burdensome charity cases. There are extensive changes that may be adapted to local contextual factors reflecting long-standing norms, values, religions, policies, existing social metrics, and institutionalized arrangements even as they embody overtones imposed by international priorities (Dallmayer, 2005; Fraser, 2005). Unraveling the relative importance of domestic arrangements and transnational influences can be a tricky task, to say the least. It involves both an in-depth grasp of domestic issues and an international perspective, an awareness of transnational forces impinging on local decisions, and sophisticated methodological and theoretical frameworks.

The commodification of social services, as it is sometimes called, is abetted by a transfer of issues of citizenship to a forum which is no longer native in its scope but transnational; marked by intergovernmental structures, multinational corporate influence, and population 
changes (Ascoli and Ranci, 2002; Phillipson, 2006:202). There is another layer of complexity added by a worldwide tendency to view a number of social issues through a medical lens (e.g., Kutchins \& Kirk, 2003) and the insecurities experienced by the citizenry in general are without parallel in world history. What might be described as apodictic, self-evident truths of tradition tend to lose their currency and help demarcate generational and participatory categories from one another.

In the face of an unswerving drive to be players on the world's stage, enhance market share and survive economic rip-tides, nation-states must balance the demands of competing claimants - leaving them few options but to make hard choices. Not only do they have to adjudicate where to put scarce resources and which groups are deserving of protection or support, but few actions are indemnified against the next economic shortfall meaning they will have to review their priorities anew each time the economic tides turn. It has always been true that in times of plenty promises about solutions to societal woes are an easy pledge to make; during times of scarcity it is a different story and keeping even the best intentioned promises oftentimes creates real conflicts. Societal-level redefinitions of what is fair and just are a common means to solutions that do not always do well by citizens in need of assistance, undermining personal sense of security and identity as well as social solidarity (Powell, 2010).

An illustration of a macro-level problem may be helpful for thinking about the type of quandary involved. As nation-states undergo economic development via participation in global commerce, per capita incomes generally increase, never mind for the moment internal disparities, life expectancies increase, and demands for healthcare mount. Continued change and desires to remain viable in the global economy mean a country will face enduring challenges in providing social safety nets, medical interventions, or financing health care protections. To focus on just the health care issue: despite subsidized provisions for indigent citizens, most healthcare coverage around the world is linked to employment and economic productivity (workfare) and as employment is destabilized so, too, is healthcare. Needless to say, employment-based systems are costly, leading to cost shifting which also serves to grant license to employers to cut jobs and move production around to minimize the expense of doing business (ironically, economic reform in former socialist countries took the same direction, e.g., Chen, 2004). For those not covered by employment-based plans, subsidized coverage is oftentimes available but financed by taxes and premiums or by governmentally mandated insurance groups saddled with high expectations and expenditures. But social policies supportive of indigent care for those not involved in economically productive activities are often singled out as a cost sink and are among the first issues put on cost-cutting agenda (Jessop, 2002).

In order to comprehend the underpinning of certain forms of inequalities it is also important to examine some of the transformations that are altering people's lives. One postmodernist reality of the $21^{\text {st }}$ century is the existence of a digital divide between those who have always known how to navigate in key-stroke technologies and those "ancients" who learned it later or not at all. Those who are comfortable with the technology have the world at their finger tips and no longer depend on local relationships or role models for solace or validation. The result is an indisputable social segmentation. Whatever norms of reciprocity had existed before are likely to falter and fray under the impact of interdicting worldviews in which the deep grammar of socialibility is no longer meaningful to those versed in the newer modes of activity. At the same time, there is an erosion of communities of like minds with shared representations cutting across society at large and fostering social solidarity. Instead they are replaced by segmented, smaller communities and a blurring of ways of knowing the world. Beck, Bonass and Lau (2003: 6) characterize the effects of technological innovation as "revolution through 
side effects" and suggest a deep-seeded societal segmentation is a likely upshot and should not be surprising. Addressing comparable consequences, Dasgupta (2006:159) phrased it succinctly: "globalization has thus created an identity crisis, since many are neither local nor global and are overloaded with changing stimuli... resulting in a 'don't care' attitude, commercial interactions among family members, a rise of individualism and a disequilibrium...."

Transnational private enterprises cannot be ignored as they are altering the landscape but they are not doing so single-handedly. It is fair to say there are both private and semi-public but non-governmental organizations (NGOs) involved. Multilateral NGOs are playing an especially crucial role and certainly a role that is influencing developing countries as they sort out their welfare regimes. For example, since the issuance of the Berg Report in 1981, the World Bank and the International Monetary Fund (IMF) have become major players on the world's stage oftentimes stipulating structural adjustments and preferred policies nation-states should adopt as a condition of support and in order to attract direct capital investments or other fiscal cooperation, including monetization. One illustration is that the World Bank began urging diminutions in pay-as-you-go (PAYG) pension provisions in favor of means-tested pensions and private provisions in the mid-1990s.

The World Bank and the IMF have been staunch advocates for over three decades for broadly defined market-led welfare policies as a preferred alternative to un- or under-funded public welfare (Dembele, 2007; Wade, 2007). Encapsulating both the criticisms and the confluence of forces fueling such a movement, McMichael (2000) asserts that the drive for economic integration pays precious little attention to nation-building, national interests, or public sector regulatory control. As a consequence, even nonprofit, social enterprises tend to be "doing good badly" (Tekula, 2010).

\section{Corollaries of Public Policy: Making Sense of Social Welfare in global Arena}

Although there is a remarkable absence of consensus, social welfare is customarily taken to mean statutory governmental intervention designed to provide supportive services and resources to those in need. Right away one question that has to be addressed revolves around eligibility requirements and stipulations of entitlement. Such issues as gender are very much a part of the state, as are discussions of family responsibilities, and welfare policies. At the risk of extreme simplification, whether women are eligible for social benefits and services in their own rights or as members of a male-breadwinner family is an abiding question whenever welfare regimes are examined. By the same token, gender ideologies are very much an aspect of poverty, labor markets and other market experiences, or the myriad inequalities that cut across the life course and through virtually every facet of experience (Calasanti, 2001; Hatch, 2000; Sainsbury, 1994; 1996).

These same forces also affect lives in even more subtle ways beyond the realm of income, access or protection. Just one case in point out of scores of similar situations should suffice to illustrate our contention. It is fair to say that institutional arrangements and structural realignments have altered time and temporality as they have altered space and other normative aspects of life. Containing our focus to the issues discussed thus far; the ebb and flow of transnational capital markets operate around the clock and penetrates virtually every aspect of governmental policy and, accordingly, daily life. Analysts generally concur that there has been a compression of time in many corners of the world as they are pulled into global market flows (Powell, 2010). As should be fairly obvious, any attenuation of earlier subjective temporal 
reckoning requires a recalibration and re-integration as new templates are incorporated into mental models of what life is about.

Analysts have asserted that globalization brings a dilation, fragmentation and acceleration of the sense of time unsettling to many (Lestienne, 2000). But, as with so many other aspects of globalization, the results do not settle on all people in equal fashion. For those who live along the margins of such change, feelings of being in-control and the clarity of their proleptic futures may be challenged as the pace, and types of engagements in their lives are restructured. Considered in a broader sense, temporal reorganization is also impacting event timing and thereby the shape of life, views of dependency, and definitions of personal worth. As normative perspectives on the shape of life are reformulated and/or personal functionality wanes, the chances increase that some subgroups within the population will lose track of their referential guidelines (Moody 2006).

In her insightful analysis of German pension provisions, Scheiwe (1994) brings a fresh perspective to discussion of how institutionalized welfare rules also structure temporality. She broadens the focus considerably in her examination of time politics and gendered times in legislation that grants standing to many market-related definitions of time and discounts others associated most frequently with women's roles outside the market or which result from discontinuous market-related activities deemed to be below time thresholds written into public welfare provisions. The gendered differentials in recognizing life's events, their timing and related circumstances serve to create essential inequalities in financial and other types of wellbeing. Time and temporality, sense of the future, and eligibility for entitlements impose structure on lives in ways that may not have been intended but are highly salient, nonetheless.

For the most part, a definition derived from the legendary Beveridge Report published in the midst of World War II in Britain has been utilized to identify and operationalize major features of the welfare state (Finer, 1999). Yet that formulation begs the question of whether that world and those circumstances still exist and how they may have been modified by postindustrial or globalizing influences. We would assert that a definition of social welfare must extend beyond questions of delivery to include its financing and function. Almost certainly the provision of non-governmental services through NGOs or volunteer agencies and programs should be included as well. Ambiguities not withstanding, it is hardly surprising that scholars looking at social welfare in a comparative focus have noted that there is a fairly direct correlation between national prosperity and percentage of GDP directed at supportive programs (Hill, 2006). However, within groups of nations (such as OECD, G-8, or G-20 countries) there are differences based on governmental types or economic developments and, we assert, in terms of underlying principles of moral economy that have shaped the formulation of welfare, whether that be public or private.

\section{Conclusion}

Inequality is an outstanding issue in the study of post-industrialism while globalization has widened its consequences such as planetary poverty and gender stratification. The potential reasons lie in the reformulation of economic power associated with burgeoning free-market economies and accompanying diffusion of instrumental rationality, standardization, commoditization, or secularism. In contrast with the economic downturn and global softening of labor markets which cry for greater social protection, the welfare state of the last century has been replaced by a competitive state of the 21 st century, as a "non-sovereign power" mindful 
of its global positioning but less powerful in shaping daily life among social forces including the role of NGOs.

However, nation-states still serve important administrative functions in a world dominated by transnational corporate interests. With few options and having to make hard choices, welfare provision has seen trends toward commodification of social services while globalization is affecting social contracts as well. In the face of all these challenges to justice and governance, there must be a twin track approach: social welfare needs to be redefined and extended while market economy must be guided by moral principles that embody fundamental human values. 


\section{CHAPTER THREE: GLOBALIZATION AND MODERNITY}

Every nation state in the world has been experiencing the most formidable economic climate for several decades. A major focus has been on transnational financial institutions and lack of regulation for consumer populations in different nation states. Hence, these problems require a global response by the international community, not just by political leaders but also by social scientists. Historically, there have been a number of social scientists who explored how the Enlightenment and its legacy have impinged upon the emergence and creation of and social science disciplines that have attempted to explain social, economic, political and cultural transformations in modernity.

The processes of globalisation in the twenty-first century are not associated with encompassing neo-liberal ideologies in the way that was the case with processes focused at level of the nation state. The world is changing at a rapid pace, and the scope and impact of change have multiple dimensions and implications that transcend geographic and cultural boundaries (Turner 2006). Hence, globalisation has transformed the way people see themselves in the world. Everyone must now reflexively respond to the common predicament of living in one world.

This provokes the formulation of contending worldviews. In a compressed world, the comparison and confrontation of worldviews are bound to produce new cultural conflict. In such conflict, old traditions and new ideas play a key symbolic role, since they can be mobilised to provide an ultimate justification for one's view of the world - a case in point being the resurgence of Islamic fundamentalist groups that combine traditionalism with a global agenda but also the response of US/UK governments that wished to promote 'democracy' and 'freedom' through a 'War on Terror' against such groups (Sands 2006). A globalised world is thus integrated but not harmonious, a single place but diverse, a construct of consciousness but prone to multiplicity and fragmentation. In that context, it is highly pertinent that critical social science steps up to the challenge and rethinks how we 'unmask' the implications of globalization and impact on modern society.

\section{The power of globalization}

Globalization has become one of the central but contested concepts of contemporary social science (Ritzer 2004). The term has further entered everyday commentary and analysis and features in many political, cultural, and economic debates. The contemporary globalised world order originates in the international organizations and regulatory systems set up after World War II - including the United Nations, General Agreement on Tariffs and Trade (now the World Trade Organization), the International Monetary Fund, and the World Bank (Smart 2007). However, the end of the Cold War was the prelude to the maturity of the concept of globalisation. From 1989 to the present, it is possible at least to imagine a 'borderless' world (Ohmae, 1990) in which people, goods, ideas, and images would flow with relative ease and the major global division between East and West had gone. A world divided by competing ideologies of capitalism and state socialism has given way to a more uncertain world in which capitalism has become the dominant economic and social system, even for the communist-led People's Republic of China.

Coinciding with these changes, a major impetus to globalisation was the development and availability of digital communication technologies from the late 1980 s with dramatic 
consequences for the way economic and personal behaviour were conducted - this has transcended to mass communication from the Internet in the 1990s to Mobile Phones from 2000 onwards (McGrew 2007). The collapse of communism in Eastern Europe and the USSR, and its modernising in China, plus growth of digital technologies further coincided with a global restructuring of the state, finance, production, and consumption associated with neo-liberalism. Coupled with this, in a post 9/11 world, there has been the recent 'War on Terror' and its implications for the re-ordering of the geo-political global agenda.

Since the advent of industrial capitalism as a feature of development of modernity, intellectual discourse has been replete with allusions to phenomena strikingly akin to those that have garnered the attention of recent theorists of globalisation (Bauman 2001). Nineteenth and twentieth century philosophy and social commentary include numerous references to an inchoate yet widely shared awareness that experiences of distance and space are inevitably transformed by the emergence of high-speed forms of technological transportation (for example, rail and air travel) and communication (the telephone) that dramatically heighten possibilities for human interaction across existing geographical and political divides (Smart 2007). Bauman has proposed nothing less than a rewriting of human history based on what he called 'the retrospective discovery' of the centrality of spatial distance and speed of communication in the constitution of all societies (Bauman 1998: 15).

Long before the introduction of the term globalisation, the appearance of novel highspeed forms of social activity generated extensive commentary about the compression of space. Indeed, Karl Marx, in 1848 formulated the first theoretical explanation of the sense of territorial compression. In Marx's account, the imperatives of capitalist production inevitably drove the bourgeoisie to:

nestle everywhere, settle everywhere, and establish connections everywhere. The juggernaut of industrial capitalism constituted the most basic source of technologies resulting in the annihilation of space, helping to pave the way for intercourse in every direction, universal interdependence of nations.

(Marx 1979 [1848]: 476).

Thus, Marx identified an ever-rising scope and volume of transnational relations, along with technologically orchestrated process of deepening spatio-temporal integration, as central to the very 'laws of motion' of capitalist development. All manner of factors might interrupt or constrain these tendencies.

However, because they were rooted in its core relations, private property and wage labour, they would keep 'reasserting themselves', and on an ever greater scale, so long as those relations were reproduced over time. The consequence is that globalisation as a spatial process that has facilitated the emergence of a new kind of global city based on highly specialised service economies that serve specific, particularised functions in the global economic system at the expense of former logics of organisation tied to manufacturing-based economies. To enable global markets to function effectively, they need to be underpinned by local managerial work that is concentrated in cities.

Further, privatisation and deregulation during the 1980s and 1990s shifted various governance functions to the corporate world, again centralising these activities in urban spaces. In post-industrial cities there is a concentration of command functions that serve as production sites for finance and the other leading industries, and provide marketplaces where firms and governments can buy financial instruments and services. Global cities become strategic sites 
for the acceleration of capital and information flows, and at the same time spaces of increasing socioeconomic polarisation.

One effect of this process has been that such cities have gained in importance and power relative to nation-states. There have emerged new 'corridors' and zones around nodal cities with increasingly relative independence from surrounding areas (Davis 2007). Globalisation simultaneously brings home and exports the processes of privatisation, competition, rationalisation, and deregulation as well as the transformation of all sectors of society through technology and the flexibilisation and deregulation of employment. As a process, debate centres on the uses of globalisation as the rationale and means by which corporate capital may transnationally pursue new low wage strategies and weaken the power of labour, women, and ethnic minority populations.

But whether globalisation is imagined or real requires rigorous analysis. The next section attempts to pull together main authors, ideas and trajectories of the globalisation and illustrate it by using key examples to consolidate understanding.

\section{Theoretical complexities of globalisation}

The theorisation of globalisation is extremely complex. Roland Robertson refers to the concept of 'global consciousness', which refers to 'the compression of the world and the intensification of consciousness of the world as a whole' (1992: 8). Through thought and action, global consciousness makes the world a single place. What it means to live in this place, and how it must be ordered, become universal questions. These questions receive different answers from individuals and societies that define their position in relation to both a system of societies and the shared properties of humankind from very different perspectives. This confrontation of worldviews means that globalisation involves 'comparative interaction of different forms of life' (1992: 27). Unlike theorists who identify globalisation with late (capitalist) modernity, Robertson sees global interdependence and consciousness preceding the advent of capitalist modernity.

However, European expansion and state formation have boosted globalisation since the seventeenth century and the contemporary shape of the world in the $19^{\text {th }}$ century, when international communications, transportation, and conflict dramatically intensified relationships across societal boundaries (Mann 2006). In that period, the main reference points of fully globalised order took shape: nation-state, individual self, world-system, societies, and one humanity.

These elements of the global situation became 'relativised' since national societies and individuals, in particular, must interpret their very existence as parts of a larger whole. To some extent, a common framework has guided that interpretive work; for example, states can appeal to a universal doctrine of nationalism to legitimate their particularizing claims to sovereignty and cultural distinction (Delanty and Isin 2003). But such limited common principles do not provide a basis for world order.

For Anthony Giddens (1991) the concept of time-space distantiation is central. This is a process in which locales are shaped by events far away and vice versa, while social relations are disembedded, or 'lifted out' from locales. For example, peasant households in traditional societies largely produced their own means of subsistence, a tithe was often paid in kind (goods, animals, or labour), money was of limited value, and economic exchange was local and particularistic. 
'Reflexive modernisation' replaced local exchange with universal exchange of money, which simplifies otherwise impossibly complex transitions and enables the circulation of highly complex forms of information and value in increasingly abstract and symbolic forms.

The exchange of money establishes social relations across time and space, which under globalisation is speeded up. Similarly, expert cultures arise as a result of the scientific revolutions, which bring an increase in technical knowledge and specialization. Specialists claim 'universal' and scientific forms of knowledge, which enable the establishment of social relations across vast expanses of time and space.

Social distance is created between professionals and their clients as in the modern medical model, which is based upon the universal claims of science. As expert knowledge dominates across the globe, local perspectives become devalued and modern societies are reliant on expert systems (Beck 1992). Trust is increasingly the key to the relationship between the individual and expert systems and is the glue that holds modern societies together. But where trust is undermined, individuals experience 'ontological insecurity' and a sense of insecurity with regard to their social reality (Giddens 1991).

Ohmae's (2005) concept of a 'borderless world' epitomises enthusiasm and the belief that globalisation brings improvement in human conditions. Ohmae describes an invisible continent' - a moving, unbounded world in which the primary linkages are now less between nations than between regions that are able to operate effectively in a global economy without being closely networked with host regions.

The invisible continent can arguably be dated to 1985 when Microsoft released its first version of Windows, CNN as a 24 hours a day new channel was launched, Cisco Systems began, the first Gateway 2000 computers were shipped, and corporations such as Sun Microsystems and Dell were starting out. Today, there has been an explosion of such corporations that affect virtually every social, economic and political relationship. Transnational corporations increasingly do not treat nation states as single entities and region states make effective points of entry into the global economy. For example, when Nestlé moved into Japan, it chose the Kansai region round Osaka and Kobe rather than Tokyo as a regional doorway (Smart 2007). This fluidity of capital is creating a borderless world in which capital moves around, chasing the best products and the highest investment returns regardless of national origin.

The Internet has changed not only the way business works but also the way people interact on a personal level - from buying and selling online to planning for retirement, managing investment and on-line bank accounts. Although, in recent times, the dark side of the Internet has revealed illegitimate ways that groups and individuals use 'hyper borderless worlds' with data espionage, data theft, credit card fraud, child pornography, extremism and terrorism - are ever more common on the internet with up to $£ 40$ billion a year made by international organised crime syndicates on the web (Huber 2004).

The Internet is a global system and decisions made on virtual 'platforms' (that are created by corporations rather than governments) determine how money moves around the globe. The emergence of 'around-the-world' 24/7 financial markets, where major cross-border financial transactions are made in cyberspace represents a familiar example of the economic face of globalisation (Schneider 2007). The definition and social construction of 'the problem' of state power is transferring from the state and its citizenry to private sector global finance. For example, Powell (2006) points to how the economic stakes and social consequences of 'ageing populations' cannot be underestimated for the upholding of power by multi-national corporations.

Looking ahead, the race is on for 'Global Custody' through the socially constructed 'Ticking of the Pensions Time Bomb', as described by the Financial Times with Europe as a 
'battleground' for the US Banks (The Bank of New York, State Street Bank, JP Morgan and Citibank) competing against the European Deutsche, BNP Paribas and HSBC for custody of the growing pensions market and the highly lucrative financial services supporting it. As further incentive to eager financial enterprises, the 'global picture' in private wealth drawn from the lucrative business of pension providing is estimated by 2007 to exceed $\$ 13,000$ billion in the USA, $\$ 10,000$ billion in Europe, and \$7,200 billion in Asia. In less developed countries, women especially have been among those most affected by the privatization of pensions and health care, and the burden of debt repayments to agencies such as the World Bank and the IMF (Walker and Naegelhe 1999).

David Harvey emphasises the ways in which globalisation revolutionises the qualities of space and time. As space appears to shrink to what Marshall McLuhan (1975) refers to as a 'global village' of telecommunications and ecological interdependencies and as time horizons shorten to the point where the present is all there is, so we have to learn how to cope with an overwhelming sense of compression of spatial and temporal worlds (Harvey 1990: 240). Timespace compression that 'annihilates' space and creates 'timeless time' is driven by flexible accumulation and new technologies, the production of signs and images, just-in-time delivery, reduced turnover times and speeding up, and both de- and re-skilling.

Harvey points for support to the ephemerality of fashions, products, production techniques, speedup and vertical disintegration, financial markets and computerized trading, instantaneity and disposability, regional competitiveness. For Harvey, flexible computer-based production in Silicon Valley or the 'Third Italy' epitomises these changes. Yet it could be argued that an exclusive focus on time-space compression would be misleading. Thrift (1994) suggests that international systems reliant upon rapid electronic communication and diffusion of data do not always result in a lessening of the importance of individual actors or localised face-to-face micro-social relations. He acknowledges that the international financial system has become, to an extent, 'disembedded from place', but emphasises that transnational financial networks generate vast amounts of data and a range of 'meanings' pertaining to the interpretation of those data.

The result is that inter-personal exchanges involving individual agency to negotiate, discuss, interpret and act upon the data are still of considerable importance. Since the vast majority of human activities is still tied to a concrete geographical location, the more decisive facet of globalisation concerns the manner in which distant events and forces impact on the local or 'glocal' situation (Tomlinson 1999: 9).

At the same time, globalisation also refers to those processes whereby geographically distant events and decisions impact to a growing degree on 'glocal' higher education (Loader 2001). For example, the insistence by powerful political leaders such as George W. Bush and Tony Blair in the Western world that the International Monetary Fund (IMF) should require that Latin and South American countries commit themselves to a particular set of economic policies might result in poorly paid teachers and researchers as well as large, understaffed lecture classes in San Paolo or Lima; the latest innovations in information technology from a computer research laboratory in India could quickly change the classroom experience of students in Tokyo.

John Urry (2005) argues that the changes associated with globalisation are so far-reaching that we should now talk of a 'theory beyond societies'. This position is informed by the alleged decline of the nation-state in a globalised world, which has led to wider questioning of the idea of 'society' as a territorially bounded entity. This in turn prepares the ground for claims to the effect that since 'society' was a core theoretical concept, the very foundations of social science discipline have likewise been undermined. The central concepts of the new socialities are space 
(social topologies), regions (interregional competition), networks (new social morphology), and fluids (global enterprises). Mobility is central to this thesis since globalisation is the complex movement of people, images, goods, finances, and so on that constitutes a process across regions in faster and unpredictable shapes, all with no clear point of arrival or departure.

Despite the contrasting theoretical understandings of globalisation, there is some measure of agreement that it creates new opportunities or threats. For example, globalisation offers new forms of cosmopolitanism (Delanty 2006) and economic growth (Smart 2007) but also new threats and global risks (Mythen 2007) such as ecological crises of global warming, climate change and environmental pollution; global health pandemics such as 'swine flu'; and international crime and terrorism.

Globalisation may be seen as encroachment and colonisation as global corporations and technologies erode local customs and ways of life, which in turn engenders new forms of protest. Giddens has argued that the effects of globalisation must also be seen as positive and that integration into the global economy increases economic activity and raises living standards. For example, Legrain (2006) claims that in 2000 the per capita income of citizens was four times greater than that in 1950. Between 1870 and 1979, production per worker became 26 times greater in Japan and 22 times greater in Sweden. In the whole world in 2000 it was double what it was in 1962. Even more significantly, Legrain (2006) argues that those nation states isolated from the global capitalist economy have done less well than those that have engaged with it. Poor countries that are open to international trade grew over six times faster in the 1970s and 1980s than those that shut themselves off from it: 4.5 percent a year, rather than 0.7 percent.

By contrast to Legrain's (2006) idealism, it can be argued that global patterns of inequality have become increasingly polarised (Estes, Biggs and Phillipson 2003). According to the United Nations, the richest 20 percent in the world 'own' 80 percent of the wealth; the second 20 percent own 10 percent; the third 20 percent own 6 percent; the fourth 20 percent own 3 percent; and the poorest 20 percent own only 1 percent. Throughout the world, 2.7 billion people live on less than $\$ 2$ per day. These global inequalities predate globalisation, of course, but there are global processes that are maintaining a highly unequal social system (Phillipson 2005). Contradictions in global society are illustrated in other ways too. The globalisation of capital may not have driven costs down in developed countries where few workers are prepared to tolerate the conditions this new model creates. Flexible global ordering systems need not just produce flexible labour, but flexible labour in excess, because to manage the supply of labour it is necessary to have a surplus. Migrants have met this need (Miles 2004). But in the wake of hostility manifest in many developed countries, especially following threats of terrorist attack in US and Europe migrants face tightening border controls and deportation of those who are not in areas where there is a shortage of skills.

Globalisation has been the focus of extensive social movement activism and 'resistance', especially to neoliberal globalism represented by bodies such as the WTO. Glasius et al. (2002) identify the emergence of a 'global civil society' in, for example, the growth of 'parallel summits' such as the 2001 Porto Alegre meeting in Brazil attended by 11,000 people to protest against the Davos (Switzerland) World Economic Forum. These are organised through multiple networks of social actors and NGOs operating on local and international levels. There may appear to be an irony that many of the internationally organised or linked social movements use globalised forms of communication (the Internet) and operate transnationally, mobilising a global consciousness and solidarities on such issues.

The major contentious claim is that globalisation is a new form of imperialism imposing US political and economic dominance over the rest of the world (Estes, Biggs and Phillipson 2003). For example, the United States represents the most significant case of privatisation as an 
element in the globalisation agenda, and a glimpse of what may come to pass for the broader community of nations. Pressures for more and more privatisation mount on the US state, as exemplified by the growth of the highly profitable $\$ 1.2$ Trillion dollar largely private medical industrial complex, which more than tripled in size during Ronald Reagan's two presidential terms during the 1980 s alone. Indeed, the medical industrial complex, comprise nearly $15 \%$ of the American economy under the Bush Administration from 2000 - 2007 even though an alarming $16 \%$ (44 million) of US citizens are uninsured for health care.

The US federal government finances around $40 \%$ of US health care, while the state limits its own activities to supporting and complementing the market (Estes and Phillipson 2003). Multinational health enterprises are an increasingly important component of the US medical industrial complex. As early as 1990, 97 US companies reported ownership of 100 hospitals with 11,974 beds in foreign countries. Pharmaceutical firms are also major global corporate players, with the total value of exported and imported pharmaceuticals estimated in excess of $\$ 110$ billion in 1998 (Phillipson and Powell 2004). Added to this:

\begin{abstract}
After three decades devoted to market rhetoric, cost containment, and stunning organizational rationalization, the net result is the complete failure of any of these efforts to stem the swelling tide of problems of access and cost. Moreover, there are alarming increases in the uninsured populations among ethnic minority groups.
\end{abstract}

(Held 2000: 183)

President Obama is currently seeking to transform the provision of healthcare in the US, but the vested interests of the privatised healthcare system are seeking to limit and oppose the main thrust of his proposals, presenting these as being 'socialist' extensions of state power. Paradoxically, however, the neo-liberal ideology of globalisation further bolsters the more restrictive limitations on the role of the state with respect to its citizens. David Held and his colleagues make the point that a distinctive feature of the present period is the extent to which:

\begin{abstract}
financial globalisation has imposed an external financial discipline on governments that has contributed to both the emergence of a more market-friendly state and a shift in the balance of power between the state and financial markets.
\end{abstract}

(Held 2000: 232)

In this respect, the political agenda of advanced capitalist states reflects in part the constraints of global finance, even though the specific impact of financial globalisation will vary greatly among states. A tangible consequence is the insertion of the operatives and 'requisites' of global finance into state policy-making in ways that frame, if not dictate, the parameters of state power.

Contrary to this, Sibeon (2004) suggests that national governments do 'matter', especially regarding globalisation and its implications for governance. It is Sibeon's (2004) contention that we must recognise subnational governance in addition to transnational and policy processes. The renewed emphasis upon locale and subnational governance is reflected in work focusing on the significance of regions in the policy process. Amin and Thrift (1995), for example, have outlined a focus upon mezo-level governance/policy networks within European regions. Jenson (1995) has suggested that, in the case of Canada, regional governance can be both utilised as a way of asserting regional/ethnic autonomy (as in Quebec), or exercised 
reluctantly (as in New Democrat-led Ontario) where subnational governments have identified a tendency for central governments to neglect or even abdicate responsibilities for maintaining standards of national economic management.

These developments can be viewed as part of a new global process of shaping the lives of present and future generations of populations in western and non-western states. The change has been variously analysed as a move from 'organised' to 'disorganised capitalism', to a shift from 'simple' to 'reflexive modernity', and to the transformation from 'fordist' to 'post-fordist economies'. The final part of this book looks ahead and provides some reflective thoughts for questioning the extent to which a 'global social theory' is warranted.

\section{The Future of a Global Social Theory?}

At this point in the twenty first century, an array of opportunities and challenges present themselves for the study of social theory. There is a need to develop a clearer perspective on the pressures facing social groups that impinge on 'race', class, age, gender, disability and sexuality as a result of global change. A significant issue is how globalisation and its impingement on local governance is transforming the everyday texture of day to day living. In this context, the need for a framework to respond to the challenge associated with globalisation is warranted. The key dimensions here are the changing and contested form of the nation state, citizenship and nationalism; the enhanced role of supra-national bodies; the increased power of multi-national corporations; and emergence and retrenching of social inequalities across the globe.

We argue that social theory should not merely provide 'critical questions' about dynamics of social relations, but rather, it is what one does with critical questions that is the cornerstone for critical theorising. In concluding this final chapter the book, we develop this theme by highlighting the main issue of globalisation that a situated social theory will need to focus on in reflexive theorising in looking ahead for the future.

A key aim of social theory is, first, the examination of the social construction of reality and critical debunking of such contingent realities. A central task for social theory concerns the need to examine the structural inequalities and power dynamics that perpetuate current understandings of social world. An analysis that accepts enlightenment assumptions about, for example, 'equality', fails to ask the key questions about why this state of affairs holds true for some rather than for others. A critical social theory must move beyond appearances and seek explanations that overturn conformist realities. Crucially, power relations, social processes and structures must be examined as they appear in everyday relations. Links must be made between the traditional and contemporary social theories between macro, micro and meso levels of analysis, so that the pull of social inequalities can be identified and the emotional experience and daily interpretation of them explored. A key issue in theoretical interpretation concerns the place and nature of 'society'. The ideas of society as a bounded self-sufficient entity most associated with the recent neo-functionalism of Alexander (2004) had become taken for granted within mainstream theorising. Such a formulation assumes there is a coherent and bounded society into which social integration is attainable. This view has become prominent by a small group of western societies, especially those associated with recent 'War on Terror' who aggressively promote nation statehood and democratic freedom (Walklate and Mythen 2007). Nevertheless, the notion of society as a sovereign entity is changing profoundly with the intensifying social forces of globalisation: 


\begin{abstract}
there are exceptional levels of global interdependence, unpredictable shock waves spill out 'chaotically' from one part to the system as a whole; there are not just societies but massively powerful empires roaming around the globe; and there is a mass mobility of people, objects and dangerous human wastes.
\end{abstract}

(Urry 2000:13)

This critical questioning of the modernist basis to society is a challenging one to social theory. In a sense the traditional formulation of 'society' is being challenged from global forces that impinges on new technology that transforms the experience of social relations (Whyte 2007). Indeed, in a networked world, everyday life is becoming detached from the protective nation state seen to be at the core of occidental modernity. Steering a path between Giddens's (1991) 'global optimists' and 'global pessimists', it may be suggested that a new formulation is required that recognises diverse and unequal networks in and through the way people interact throughout their lives across national, transnational and sub-cultural contexts. A major dimension of inequities impinges on debates on issues such as climate change, power of multinational corporations, and third world countries of debt repayment (Mythen 2007; Phillipson 2006). The phenomenon of globalisation has transformed debates within social theory to the extent that it has re-ordered concepts typically used by social theorists across micro-macro continuum (Bauman 1998).

Ideas associated with the idea of modernity, the state, gender, class relations, ageing and ethnicity have retained their importance but their collective and individualised meaning is different and fragmented in the context of the influence of global actors and institutions (Mythen 2007).

A contentious point is that accepting the importance of globalisation also strengthens the case for rethinking social theory through re-assertion of macro analysis. Hagestad and Dannefer (2001: 66) note that the costs of micro analysis has been significant in 'hampering' our ability to address what we mean by society in the context of global economic and technological change'. Given the explanatory role of social theory, globalisation is setting major new challenges in terms of interaction between individuals, communities and nation states and the global structure within which these are constructed, contested and nested. Analysing the interpretation of daily life may be more appropriately assessed in the contexts of networks and flows characteristic of global society, these producing a loosening in those attachments which have traditionally embedded people to locative settings: for Marxists in social class and for Feminists in gendered configurations. With globalisation, these attachments are maintained but recontextualised and re-embedded with the influence of transnational communities, corporations and international governmental organisations producing new agendas and challenges for how we understand 'modern society' (Turner 2006).

Further, the nature of 'citizenship' and 'rights' so heavily influenced by Enlightenment philosophy are both heavily contested under the lead of the complex and commanding influences of powerful non-democratic intergovernmental structures such as the World Bank and International Monatory Fund (IMF), private multinational corporations such as banks and western states that are under new pressures associated with accelerating demography and migration. This contrasts sharply with the Enlightenment period which saw rights arguably independently defined and negotiated through various manifestations of British, European and American nation building and sovereign state-based power.

It may also be suggested that democratic rights have become more fragmented as well as individualised. What has changed is the duty and necessity to cope with these risks that are 
being increasingly transferred to families (Bauman 2000). The new social construction of everyday life may be defined as a global problem and issue but the social reconstruction of how experience globalisation is being cast as a personal rather than a collective responsibility. This development also implies an important role for social theory in interconnecting macro and micro perspectives with new approaches in order to understand how global processes contribute to the reshaping of the institutions in which the experiences of social groups are embedded.

A further task must be to construct new social theories about the nature of individualisation in light of more fluid borders surrounding nation states. Important questions concern whether and how people, socially differentiated, are facilitated or constrained by the spread of mobile communities along with more varied forms of belonging and citizenship. Social theory will be profoundly influenced by the 'development of a common consciousness of human society on a world scale and an increased awareness of the totality of human social relations as the largest constitutive framework of all relations' (Shaw 2002:12).

A further issue concerns the extent to which social theory may challenge the dominant institutions that reproduce and perpetuate social divisions in society. Applications of the policy sciences take for granted existing systems of capitalism as scholars work largely within 'definitions of the situation' that are framed by classical economic theories, assumptions and models of cost-effectiveness and individual level outcomes. The end result is that only a limited array of potentially viable policy options assuring the serious consideration of only incremental changes that will do little to alter the underlying structural economic problems facing social groups such as, for example, older people (Powell 2006).

In challenging this, there is a need for theorising that examines the structural forces and social processes that profoundly shape individual and group experience in the global community of the first, second and third worlds. Theoretical development from a critical perspective seeks to illuminate alternative understandings and a vision to 'what is possible'. It is a requisite to lifting the ideological veil of scientific objectivity that obscures and mystifies inequality and social injustice in a society and economy that prioritises the production of goods and services primarily for its economic and exchange value rather than for its social value and capacity to meet human needs across the world.

\section{BIOGRAPHY}

Professor Jason L. Powell BA (Hons), MA, Ph.D, FRSA is Professor of Social Gerontology and Associate Dean of Faculty of Health and Life Sciences at University of Coventry. He holds an Honorary Fellowship at University of Liverpool; Honorary Professor at Australia-Asia Research and Education Foundation at Tasmania University; Visiting Research Fellow at Oxford; and recently invited as Visiting Scholar at Harvard University. He has been Visiting Professor in Canada, US, Australia, Africa and Jordan. He was nominated and elected to Fellowship of the British Royal Society of Arts (FRSA) in recognition of his research. He has strong interests in social theory, ageing, power and identity. He is author of Social Theory and Ageing (2006) which was part of Charles Lemert's distinguished 'New Social Formations' book series, Rowman and Littlefield: New York.

\section{Bibliography}

[1] Bauman, Z. (1998). Globalization: The Human Consequences, Polity Press, Cambridge.

[2] Cook, I.G. (1999). Pressures of Globalisation, Can These Be Managed?, Proceedings of the World Management Conference, Beijing.

[3] Delanty, G. and Isin E. (eds) (2003). Handbook of Historical Sociology, London: Sage. 
[4] Dummer, T.J.B. and Cook, I.G. (2008). Health in China and India: A Cross-Country Comparison in a Context of Rapid Globalisation, Social Science and Medicine, 67, 590-605.

[5] Durkheim (1896).

[6] Estes, C.L., Biggs, S. and Phillipson, C. (2003). Social Theory, Social Policy and Ageing: A Critical Introduction, Maidenhead: Open University.

[7] Borja, J. and Castells, M. (1997). Local \& Global: Management of Cities in the Information Age, Earthscan, London.

[8] Carey, G. and Wolfensohn, J. (1999). Creditors of the Poor - Yes, All of Us, Comment \& Analysis The Guardian, June 15th.

[9] Coffey, W.J. (1996). The 'newer' international division of labour, in Daniels, P.W. and Lever, W.F. (eds), The Global Economy in Transition, Addison Wesley Longman, Harlow, Essex.-

[10] Cook, I.G. (1997). Contextualising Steel: Changing Locational Factors in the Steel Industry, International Symposium on Steel Industry Development and Management, Baoshan, May.

[11] Cook, I.G. (2000a). Urban and Regional Pressures of Development, Chapter 2 in Cannon, T. (ed.), China: Resources, Development, Environment, Macmillan, London, in press.

[12] Cook, I.G. (2000b), Interpreting A Multiplicity of Regions: Globalisation, Regionalisation and Pacific Asia, submitted book.

[13] Cook, I.G. and Murray, G. (2000). China's Third Revolution: Tensions in the Transition to a Post-Communist China, Curzon, London.

[14] Cook, I.G. and Wang, Y. (1998). Foreign direct investment in China: patterns, processes, prospects, Chapter 6 in Cook, I.G., Doel, M.A., Li, R.Y.F. and Wang, Y. (eds), Dynamic Asia: Business, Trade and Economic Development in Pacific Asia, Ashgate, Aldershot, 177-208.

[15] Dawkins, W. (1997). 'Sense of Unease Over a Britain Out in the Cold: Toyota Does Not Speak For All But There is Vague Concern in Japan', Financial Times, January 31st.

[16] Denny, C. and Elliott, L. (1999). Fears of Big Talk But Little Money, The Guardian, June 14th, 11 .

[17] Dicken, P. (1993). 'The Growth Economies of Pacific Asia in Their Changing Global Context', Chapter Two in Dixon, C. and Drakakis-Smith (eds), Economic and Social Development in Pacific Asia, Routledge, London., 22-42.

[18] Dicken, P. (1998). Global Shift: Transforming the World Economy, Third Edition, Paul Chapman, London.

[19] Finance and Development (1992). Recent Trends in FDI for the Developing World, 29, 50-51.

[20] Giddens, A. (1998). The Third Way: The Renewal of Social Democracy, Polity Press, Cambridge. 
[21] Gifford, S. (1994), Japan Among the Powers 1890-1990, Yale University Press, New Haven and London.

[22] Hutton, W. (1996). The State We're In, Vintage, London, Revised Edition.

[23] Jilberto, A.E.F. and Mommen, A. (1998), 'Globalization Versus Regionalization', Chapter One in Jilberto, A.E.F. and Mommen, A. (eds), Regionalization and Globalization in the Modern World Economy: Perspectives on the Third World and Transitional Economies, Routledge, London, 1-26.

[24] Khong, Cho-Oon (1996), Pacific Asia as a Region: the View from Business, Chapter 7 in Cook, I.G., Doel, M.A. and Li, R. (eds), Fragmented Asia: Regional Integration and National Disintegration in Pacific Asia, Avebury, Aldershot, 167-180.

[25] Lee, B-T and Bahrin, T.S. (1998), Wither the Borders? Towards a New Dimension of Geographical Differentiation, Chapter 1 in Lee, B-T and Bahrin, T.S. (eds), Vanishing Borders: The New International Order of the 21st Century, Ashgate, Aldershot, 3-13.

[26] Lee, S. (1998), Managed or Mismanaged Trade? US-Japan Trade Relations During the Clinton Presidency, Chapter 7 in Cook, I.G., Doel, M.A., Li, R. and Wang, Y. (eds), Dynamic Asia: Business, Trade and Economic Development in Pacific Asia, Ashgate, Aldershot, 209-233.

[27] Liu, Fu-Kuo (1996), Industrial Development and the Impetus to Regional Economic Integration in Pacific Asia, Chapter 6 in Cook, I.G., Doel, M.A. and Li, R. (eds), Fragmented Asia: Regional Integration and National Disintegration in Pacific Asia, Avebury, Aldershot, 137-166.

[28] Martin, H-P and Schumann, H. (1997), The Global Trap: Globalization and the Assault on Prosperity and Democracy, Zed, London.

[29] Martin, R. and Rowthorn, R. (1986) (eds), The Geography of De-industrialisation, Macmillan, London.

[30] Nsouli, S.M. (1999), A Decade of Transition: An Overview of the Achievements and Challenges, Finance and Development, 36, 2, 2-5.

[31] Ohmae, K. (1990), The Borderless World: Power and Strategy in the Interlinked Economy, Harper Collins, London.

[32] Ouattara, A.D. (1999), Africa: An Agenda for the 21st Century, Finance and Development, 36, 1, 2-5.

[33] Postel-Vinay, K. (1996), Local Actors and International Regionalism: the Case of the Sea of Japan Zone, The Pacific Review, 9, 489-503.

[34] Pyle, K.B. (1996), The Making of Modern Japan, D.C. Heath and Co., Lexington, Mass., 2nd Edition.

[35] Robertson, D. (1997), 'Introduction: East Asian Trade and the New World Trade Order', in Robertson, D. (ed.), East Asian Trade After the Uruguay Round, Cambridge University Press, Cambridge, 1-17.

[36] Rozman, G. (1998), Flawed regionalism: reconceptualizing Northeast Asia in the 1990s, The Pacific Review, 11, 1-27.

[37] Samuelson, R.J. (1999), Spotlight: The Troubled World Economy, Brittanica Book of the Year: Events of 1998, Encyclopaedia Britannica, Chicago, 450. 
[38] Simmons, I.G. (1996), Changing the Face of the Earth: Culture, Environment, History, Blackwell, Oxford, 2nd Edition.

[39] Soros, G. (1998), The Crisis of Global Capitalism: Open Society Endangered, Little, Brown and Co., London.

[40] Wong, J. (1999), China's Dynamic Economic Growth in the Context of East Asia, Keynote book presented to the Chinese Economic Association (UK) Annual Conference on The Chinese Economy and Industry in the 21st Century, Middlesex Business School, London, March.

[41] Annual World Wealth Report (2008). 12 ${ }^{\text {th }}$ Annual World Wealth Report. New York: Merrill Lynch/ Capgemini.

[42] Appadurai, A. (2002). Grassroots globalization and the research imagination. In A. Appadurai (Ed.). Globalization (pp. 1-21). Durham, NC: Duke University Press.

[43] Arias, A. O., \& Logan, B.I. (2002) Conclusion: From globalization towards universalization in the twenty-first century. In B. I. Logan (Ed.). Globalization, the third world state and poverty-alleviation in the twenty-first century (pp.197-202). Aldershot, UK: Ashgate.

[44] Ascoli, U., \& Ranci, C. (2002). The context of new social policies in Europe. In U. Ascoli \& C. Ranci (Eds.). Dilemmas of the welfare mix: The new structure of welfare in an era of privatization (pp. 1-24). New York: Kluwer Academic/Plenum Publishers.

[45] Bauman, Z. (1998) Globalization; The human consequences. New York: Columbia University Press.

[46] Beck, U. (1999). World risk society. Cambridge: Polity Press.

[47] Beck, U., Bonss, W. \& Lau, C. (2003). "The theory of reflexive modernization: Problematic, hypotheses and research programme." Theory, Culture \& Society, 20, 1-33.

[48] Calasanti, T. M. (2001). Gender, social inequalities and aging. Walnut Creek, CA: AltaMira.

[49] Castells, M. (2000). The rise of the network society: The information age: Economy, society and culture, Volume 1 ( $2^{\text {nd }}$ edition). Oxford, UK: Blackwell.

[50] Chen, S. (2004). Public Policy and Development Strategy: Theoretical, Comparative, and Historical Perspectives Illustrated with the Case of the Chinese State. Dubuque, IA: Kendall/Hunt Publishing.

[51] Chen, S., \& Ravallion, M. (2007). The Changing Profile of Poverty in the World. 2020 FOCUS BRIEF on the World's Poor and Hungry People. Washington, D.C.: International Food Policy Research Institute.

[52] Chen, Y-P., \& Turner, J. (2006). Economic resources: Implications for aging policy in Asia. In H. Yoon \& J. Hendricks (Eds.). Handbook of Asian Aging (pp. 67-90). Amityville, NY: Baywood.

[53] Cerny, P. G., \& Evans, M. (2004). Globalisation and public policy under new labour. Policy studies, 25, 51-65.

[54] Clark, G. (2007). A farewell to alms: A brief economic history of the world. Princeton, NJ: Princeton University Press. 
[55] Cook, I and Powell, J (2010) Aging in Asia. New York: Nova Science Publishers

[56] Dallmayer, F. (2005). Small Wonder: Global Power and its Discontents. Lanham, MD: Rowman \& Littlefield.

[57] Dasgupta, S. (2006). Globalization and its future shock. In S. Dasgupta \& R. Kiely (Eds.), Globalization and after (pp. 143-183). Thousand Oaks, CA: Sage.

[58] Deacon, B., Hulse, M., \& Stubbs, P. (1997). Global social policy: International organizations and the future of welfare. Thousand Oaks, CA: Sage.

[59] Dembele, D. M. (2007). The International Monetary Fund and the World Bank in Africa: A disastrous record. In V. Navarro (Ed.), Neoliberalism, globalization and Inequalities: Consequences for health and quality of life (pp. 369-377). Amityville, NY: Baywood.

[60] Esping-Andersen, G. (2002). Why we need a new welfare state. Oxford: Oxford University Press.

[61] Esping-Andersen, G. (1990). Three worlds of welfare capitalism. Cambridge: Polity Press.

[62] Finer, C. (1999). Trends and developments in welfare states. In J. Clasen (Ed.). Comparative social policy: Concepts, theories and methods (pp. 15-33). Oxford: Blackwell.

[63] Foucault, M. (1978). The history of sexuality. New York: Pantheon Books.

[64] Fraser, N. ( 2005).Transnationalizing the public sphere. In M. Pensky (Ed.), Globalizing Critical Theory (pp. 37-47). Lanham, MD: Rowman \& Littlefield.

[65] Geertz, C. (1973). The Interpretation of Cultures. New York: Basic Books.

[66] Giddens A. (1990). The Consequences of Modernity. Cambridge: Polity Press.

[67] Hart, G. (2002). Disabling globalization: Places of power in post-apartheid South Africa. Berkeley, CA: University of California Press.

[68] Hatch, L. R. (2000). Beyond gender differences. Amityville, NY: Baywood.

[69] Hendricks, J. (2005). Moral economy and aging. In M. L. Johnson (Ed.). Cambridge handbook of age and ageing (pp. 510-517). Cambridge: Cambridge University Press.

[70] Hill, M. (2006). Social policy in the modern world. Oxford: Blackwell.

[71] Hoogvelt, A. (1997). Globalization and the postcolonial world: The new political economy of development. Baltimore, MD: Johns Hopkins University Press.

[72] Hudson, J., \& Lowe, S. (2004). Understanding the policy process: Analysing Welfare policy and practice. Bristol, UK: Polity Press.

[73] Jessop, B. (2002). The future of the capitalist state. Bristol, UK: Polity Press.

[74] Kearney, M. (1995). The local and the global: The anthropology of globalization and transnationalism. Annual Review of Anthropology, 24: 547-565.

[75] Kennett, P. (2001). Comparative social policy. Buckingham: Open University Press.

[76] Kutchins, H., \& Kirk, S. A. (2003). Making Us Crazy - DSM: The Psychiatric Bible and the Creation of Mental Disorders. New York: Free Press. 
[77] Lestienne, R. (2000). Time and globalization: does the emergence of a global identity entail a loss of individualities. Time and Society, 9, 289-291.

[78] Mabbett, D., \& Bolderson, H. (1999). Theories and methods in comparative social policy. In J. Clasen (Ed.). Comparative social policy: Concepts, theories and methods (pp. 34-56). Oxford: Blackwell.

[79] McMichael, P. (2000). Development and social change. Thousand Oaks, CA: Pine Forge Press.

[80] Mishra, R. (1999). Globalization and the welfare state. Cheltenham, UK: Edward Elgar.

[81] McMichael, P. (2000). Development and social change. Thousand Oaks, CA: Pine Forge Press.

[82] Navarro, V. (2007). Neoliberalism as a class ideology; or, the political causes of the growth of inequalities. In V. Navarro (Ed.), Neoliberalism, globalization and inequalities: Consequences for health and quality of life (pp. 9-23). Amityville, NY: Baywood.

[83] Phillipson, C. (2006). Ageing and globalization. In J. Vincent, C. Phillipson, \& M. Downs (Eds.). The futures of old age (pp. 201-207). Thousand Oaks, CA: Sage.

[84] Powell, J and Cook, I.G. (Eds.) (2010) Aging in Asia. Nova Science: NY

[85] Powell, J (2010) Aging, Theory and Globalization. Nova Science: NY

[86] Sainsbury, D. (1996). Gender equality and welfare states. Cambridge: Cambridge University Press.

[87] Sainsbury D. (Ed.). (1994). Gendering Welfare States. Thousand Oaks, CA: Sage.

[88] Scheiwe, K. (1994). German pension insurance, gendered times and stratification. In D. Sainsbury (Ed.). Gendering Welfare States (pp. 132-149). Thousand Oaks, CA: Sage.

[89] Shalev, M. (2007). Book review of G. J. Kasza One world of welfare: Japan in comparative perspective. In American Journal of Sociology, 112, 905-907.

[90] Steger, M. B. (1997). The future of globalization. In A. D. King (Ed.). Culture, globalization and the World-System (pp. 116-129), Minneapolis, MN: University of Minnesota Press.

[91] Tekula, Rebecca (2010). Social Enterprise: Innovation or Mission Distraction? Working Book, Helene and Grant Wilson Center for Social Entrepreneurship, Pace University.

[92] Townsend, P. (2007). Using human rights to defeat ageism: Dealing with policyinduced 'structured dependency.' In M. Bernard \& T. Scharf (Eds.), Critical perspectives on ageing societies (pp. 27-44). Bristol, UK: Polity Press.

[93] Wade, R. H. (2007). The causes of increasing world poverty and inequality; or, what the Matthew Effect prevails. In V. Navarro (Ed.), Neoliberalism, globalization and inequalities: Consequences for health and quality of life (pp. 119-141). Amityville, NY: Baywood.

[94] Yapa, L. (2002). Globalization and poverty: From a poststructural perspective. In B. I. Logan (Ed.). Globalization, the third world state and poverty-alleviation in the twentyfirst century (pp.15-29). Aldershot, UK: Ashgate.

[95] Adam, B. (1995) Timewatch: The Social Analysis of Time. Cambridge: Polity. 
[96] Adorno, T. and Horkheimer, M. (1979) Dialectic of Enlightenment. Originally published in 1944. Translated by Cumming, J. London: Verso.

[97] Adorno, T., Frankel-Brunswik, E., Levinson, D. and Sanford, R. (1950) The Authoritarian Personality. New York: Harper \& Row.

[98] Adorno, T., Albert, H., Dahrendorf, R., Habermas, J., Pilot, H. and Popper, K. R. (1976) The Positivist Dispute in German Sociology. Translated by Adey, G. and Frisby, D. London: Heinemann.

[99] Albrow, M. (1987) 'The Application of the Weberian Concept of Rationalization to Contemporary Conditions'. In Lash, S. and Whimster, S. (eds). Albrow, M. (1990) Max Weber's Construction of Social Theory. London: Macmillan.

[100] Alexander, J. C. (1984) 'The Parsons Revival in German Sociology'. Sociological Theory 2: 394-412.

[101] Alexander, J. C. (ed.) (1985) Neofunctionalism. Beverly Hills, Calif. and London: Sage.

[102] Alexander, J. C. (1990) 'The Centrality of the Classics'. In Giddens, A. and Turner, J. (eds).

[103] Alexander, J. C. (1991) 'Habermas and Critical Theory: Beyond the Marxian Dilemma?' In Honneth, A. and Joas, H. (eds).

[104] Alexander, J. C. (1995) Fin de Siecle Social Theory: Relativism, Reduction and the Problem of Reason. London: Verso.

[105] Almquist E. M. (1979) 'Black Women and the Pursuit of Equality'. In Freeman, J. (ed.).

[106] Althusser, L. (1969) For Marx. Translated by Brewster, B. Harmondsworth: Penguin.

[107] Anderson, R., Hughes, J. and Sharrock, W. (1986) Philosophy and the Human Sciences. London: Routledge.

[108] Archer, M. S. (1989) Culture and Agency: The Place of Culture in Social Theory. Cambridge: Cambridge University Press.

[109] Archer, M. S. (1990) 'Human Agency and Social Structure: A Critique of Giddens'. In Clark, J., Modgil, C. and Modgil, S. (eds).

[110] Armstrong, T. J. (ed.) (1992) Michel Foucault: Philosopher. Translated by Armstrong, T. J. London: Harvester Wheatsheaf.

[111] Aronowitz, S. (1992) 'The Tensions of Critical Theory: Is Negative Dialectics All There Is?' In Seidman, S. and Wagner, D. (eds).

[112] Assister, A. (1983) 'Did Man Make Language?' Radical Philosophy 34: 25-29.

[113] Atkinson, J. M. (1978) Discovering Suicide: Studies in the Social Organisation of Sudden Death. London: Macmillan.

[114] Atkinson, J. M. and Heritage, J. C. (eds) (1984) Structures of Social Action: Studies in Conversation Analysis. Cambridge: Cambridge University Press.

[115] Atkinson, P. (1988) 'Ethnomethodology: A Critical Review'. Annual Review of Sociology 14: 441-465.

[116] Austin, J. (1976) How to Do Things with Words. Oxford: Oxford University Press. 
[117] Barber, W. J. (1981) A History of Economic Thought. Harmondsworth: Penguin.

[118] Barrett, M. (1988) Women's Oppression Today: The Marxistl Feminist Encounter. Revised edn. London: Verso.

[119] Barrett, M. and Phillips, A. (eds) (1992) Destabilizing Theory: Contemporary Feminist Debates. Cambridge: Polity.

[120] Baudrillard, J. (1981) For a Critique of the Political Economy of the Sign. Originally published in 1972. St Louis, Miss.: Telos.

[121] Baudrillard, J. (1983) Simulations. New York: Semiotext(e).

[122] Baudrillard, J. (1993) 'Hyperreal America'. Translated by Macey, D. Economy and Society 22(2): 243-252.

[123] Baudrillard. J. (1995) The Gulf War Did Not Take Place Indiana: Indiana University Press.

[124] Baudrillard, J (2005) The Intelligence of Evil or the Lucidity Pact. NY: Palgrave.

[125] Bauman, Z. (1978) Hermeneutics and Social Science: Approaches to Understanding. London: Hutchinson.

[126] Bauman, Z. (1987) Legislators and Interpreters: On Modernity, Post-Modernity and Intellectuals. Cambridge: Polity.

[127] Bauman, Z. (1989) Modernity and the Holocaust. Cambridge: Polity.

[128] Bauman, Z. (1991) Modernity and Ambivalence. Cambridge: Polity.

[129] Bauman, Z. (1992) Intimations of Postmodernity. London: Routledge.

[130] Bauman, Z (2000) Liquid Modernity. Cambridge: Polity.

[131] Bauman, Z (2001) “Consuming Life.” Journal of Consumer Culture 1: 9-29.

[132] Bauman, Z (2003) Liquid Love. Cambridge: Polity.

[133] Beck, U. (1992) Risk Society: Towards a New Modernity. London: Sage.

[134] Beck, U., Giddens, A. and Lash, S. (1994) Reflexive Modernization: Politics, Tradition and Aesthetics in the Modern Social Order. Cambridge: Polity.

[135] Becker, H. (1963) Outsiders: Studies in the Sociology of Deviance. New York: Free Press.

[136] Beechey, V. (1986) 'Women and Employment in Contemporary Britain'. In Beechey, V. and Whitelegg, E. (eds).

[137] Beechey, V. and Whitelegg, E. (eds) (1986) Women in Britain Today. Milton Keynes: Open University Press.

[138] Beetham, D. (1974) Max Weber and the Theory of Modern Politics. London: Allen \& Unwin.

[139] Bell, D. (1960) The End of Ideology. New York: Collier.

[140] Beloff, M. (1954) The Age of Absolutism: 1660-1815. London: Hutchinson.

[141] Bendix, R. (1977) Max Weber: An Intellectual Portrait. Berkeley, Calif.: University of California Press. 
[142] Benhabib, S. (1992) Situating the Self: Gender, Community and Postmodernism in Contemporary Ethics. Cambridge: Polity.

[143] Benjamin, A. (ed.) (1991) The Problems ofModernity: Adornoand Benjamin. London: Routledge.

[144] Benson, D. (1974) 'Critical Note: A Revolution in Sociology'. Sociology 8: 125-129.

[145] Benton, T. (1977) Philosophical Foundations of the Three Sociologies. London: Routledge \& Kegan Paul.

[146] Berger, P. L. and Luckmann, T. (1 967) The Social Construction of Reality: A Treatise in the Sociology of Knowledge. New York: Anchor.

[147] Berman, M. (1988) All That is Solid Melts into Air: The Experience of Modernity. $2^{\text {nd }}$ edn. London: Verso.

[148] Berman, M. (1993) 'Why Modernism Still Matters'. In Lash, S. and Friedman, J. (eds).

[149] Bernauer, J. and Rasmussen, D. (eds) (1991) The Final Foucault. Cambridge, Mass.: MIT Press.

[150] Bernstein, R. (1983) Beyond Objectivism and Relativism: Science, Hermeneutics and Praxis. Oxford: Basil Blackwell.

[151] Bernstein, R. (1985a) 'Introduction'. In Bernstein, R. (ed.).

[152] Bernstein, R. (ed.) (1985b) Habermas and Modernity. Cambridge: Polity.

[153] Bershady, H. J. (1991) 'Practice against Theory in American Sociology: An Exercise in the Sociology of Knowledge'. In Robertson, R. and Turner, B. S. (eds)

[154] Best, S. (1 994) 'The Commodification of Reality and the Reality of Commodification:

[155] Baudrillard, Debord, and Postmodern Theory'. In Kellner, D. (ed.).

[156] Bhaskar, R. (1993) Dialectic: The Pulse of Freedom. London: Verso.

[157] Bierstedt, R. (1 979) 'Sociological Thought in the Eighteenth Century'. In Bottomore, T. and Nisbet, R. (eds).

[158] Billig, M. (1994) 'Sod Baudrillard! Or Ideology Critique in Disney World'. In Simons, H. W. and Billig, M. (eds).

[159] Bittner, E. (1974) 'The Concept of Organization'. Originally published in 1965. Reprinted in Turner, R. (ed.).

[160] Blackman, H. J. (ed.) (1967) Objections to Humanism. Harmondsworth: Penguin.

[161] Blackman, H. J. (1968) Humanism. Harmondsworth: Penguin.

[162] Bloor, D. (1983) Wittgenstein: A Social Theory of Knowledge. London: Macmillan.

[163] Blumer, H. (1937) 'Social Psychology'. In Schmidt, E. P. (ed.).

[164] Blumer, H. (1969) Symbolic Interactionism: Perspective and Method. Englewood Cliffs, NJ: Prentice-Hall.

[165] Blumer, H. (1972) 'Society as Symbolic Interaction'. In Rose, A. (ed.).

[166] Blumer, H. (1983) 'Going Astray with a Logical Scheme'. Reprinted in Plummer, K. (ed.) (1991 a). 
[167] Boden, D. and Zimmerman, D. H. (eds) (1993) Talk and Social Structure: Studies in Ethnomethodology and Conversation Analysis. Cambridge: Polity.

[168] Bosanquet, T. (1967) 'Auguste Comte and the Positive Philosophers'. In Hearnshaw, F. J. C. (ed.).

[169] Bottomore, T. (1979) 'Marxism and Sociology'. In Bottomore, T. and Nisbet, R. (eds).

[170] Bottomore, T. and Nisbet, R. (1979a) 'Structuralism'. In Bottomore, T. and Nisbet, R. (eds).

[171] Bottomore, T. and Nisbet, R. (eds) (1979b) A History of Sociological Analysis. London: Heinemann.

[172] Bourdieu, P. (1 962) The Algerians. Boston, Mass.: Beacon.

[173] Bourdieu, P. (1977) Outline of a Theory of Practice. Translated by Nice, R. Cambridge: Cambridge University Press.

[174] Bourdieu, P. (1981) 'Men and Machines'. In Knorr-Cetina, K. and Cicourel, A. (eds).

[175] Bourdieu, P. (1984) Distinction: A Social Critique of the Judgement of Taste. Translated by Nice, R. London: Routledge \& Kegan Paul.

[176] Bourdieu, P. (1988) Homo Academicus. Translated by Collier, P. Cambridge: Polity.

[177] Bourdieu, P. (1989) 'Social Space and Symbolic Power'. Sociological Theory 7(1): 14-25.

[178] Bourdieu, P. (1990) In Other Words: Essays Towards a Reflexive Sociology. Translated by Adamson, M. Cambridge: Polity.

[179] Bourdieu, P. (1991a) 'Meanwhile, I Have Come to Know All the Diseases of Sociological Understanding: An Interview'. Conducted by Krais, B. In Bourdieu, P., Chamboredon, J.-C. and Passeron, J.-C.

[180] Bourdieu, P. (1 991 b) The Political Ontology of Martin Heidegger. Translated by Collier, P. Cambridge: Polity.

[181] Bourdieu, P. (1992a) The Logic of Practice. Translated by Nice, R. Originally published in 1980 as Le Sens pratique. Cambridge: Polity.

[182] Bourdieu, P. (1992b) Language and Symbolic Power. Edited and introduced by Thompson, J. B. Translated by Raymond, G. and Adamson, M. Cambridge: Polity.

[183] Bourdieu, P. (1993a) 'Concluding Remarks: For a Sociogenetic Understanding of Intellectual Works'. In Calhoun, C., LiPuma, E. and Postone, M. (eds).

[184] Bourdieu, P. (1993b) Sociology in Question. Translated by Nice, R. London: Sage.

[185] Bourdieu, P. (1995) The Rules of Art: Genesis and Structure of the Literary Field. Translated by Emanuel, S. Cambridge: Polity.

[186] Bourdieu, P. (2000) Pascalian Meditations. Cambridge: Polity Press. Trans. Richard Nice.

[187] Bourdieu, P. and Passeron, J.-C. (1990) Reproduction in Education, Society and Culture. 2nd edn. London: Sage. 
[188] Bourdieu, P., Chamboredon, J.-C. and Passeron, J.-C. (1991) The Craft of Sociology: Epistemological Preliminaries. Edited by Krais, B. Translated by Nice, R. New York: Walter de Gruyter.

[189] Bourdieu, P. and Wacquant, L. J. (1992) An Invitation to Reflexive Sociology. Cambridge: Polity.

[190] Bourdieu, P, Passeron, J.-C. and de Saint Martin, M., with contributions by Baudelot, C. and Vincent, G. (1994) Academic Discourse: Linguistic Misunderstanding and Professorial Power. Translated by Teese, R. Cambridge: Polity.

[191] Boyne, R. (1991) 'Power-Knowledge and Social Theory: The Systematic Misrepresentation of Contemporary French Social Theory in the Work of Anthony Giddens'. In Bryant, C. and Jary, D. (eds).

[192] Brenner, J. and Ramas, M. (1990) 'Rethinking Women's Oppression'. In Lovell, T. (ed.).

[193] Bretherton, C. (1996) 'Introduction: global politics in the 1990s' in Bretherton, C. and Ponton, G. (eds) Global Politics: An Introduction Oxford, Blackwell

[194] Bronner, S. (1994) Of Critical Theory and its Theorists. Oxford: Blackwell.

[195] Bronner, S. and Kellner, D. (eds) (1989) Critical Theory and Society: A Reader. London: Routledge.

[196] Bronowski, J. and Mazlish, B. (1970) The Western Intellectual Tradition. Harmondsworth: Penguin.

[197] Brown, P. and Jordanova, L. J. (1981) 'Oppressive Dichotomies: The Nature/Culture Debate'. In Cambridge Women's Studies Group (eds).

[198] Brubaker, R. (1985) 'Rethinking Classical Theory: The Sociological Vision of Pierre Bourdieu'. Theory and Society 14(6): 745-775.

[199] Brunkhorst, H. (1992) 'Culture and Bourgeois Society: The Unity of Reason in a

[200] Divided Society'. In Honneth, A., McCarthy, M., Offe, C. and Wellmer, A. (eds) (1992).

[201] Brunt, R. and Rowan, C. (eds) (1982) Feminism, Culture and Politics. London: Lawrence \& Wishart.

[202] Bryant, C. and Jary, D. (eds) (1991) Giddens Theory of Structuration: A Critical Appreciation. London: Routledge.

[203] Bulmer, M. (1984) The Chicago School of Sociology: Institutionalization, Diversity, and the Rise of Sociological Research. Chicago: University of Chicago Press.

[204] Burchell, G., Gordon, C. and Miller, P. (eds) (1991) The Foucault Effect: Studies in Govermentality. London: Harvester Wheatsheaf.

[205] Burke, K. (1969) A Grammar of Motives. Originally published in 1945. Berkeley, Calif.: University of California Press.

[206] Burke, P. (1980) Sociology and Histo y. London: Allen \& Unwin.

[207] Burns, T. (1992) Erving Goffman. London: Routledge. 
[208] Button, G. (1991a) 'Introduction: Ethnomethodology and the Foundational Respecification of the Human Sciences'. In Button, G. (ed.).

[209] Button, G. (ed) (1991b) Ethnomethodology and the Human Sciences. Cambridge: Cambridge University Press.

[210] Button, G. and Casey, N. (1984) 'Generating Topic: The Use of Topic Initial Elicitors'. In Atkinson, J. M. and Heritage, J. (eds).

[211] Bynner, J. and Stribley, K. (eds) (1979) Social Research: Principles and Procedures. Milton Keynes: Open University Press.

[212] Calhoun, C. (ed.) (1994) Social Theory and the Politics of ldentity. Oxford: Blackwell.

[213] Calhoun, C. (1995) Critical Social Theory: Culture, History, and the Challenge of Difference. Oxford: Blackwell.

[214] Calhoun, C., LiPuma, E. and Postone, M. (eds) (1993) Bourdieu: Critical Perspectives. Cambridge: Polity.

[215] Callinicos, A. (1990) Against Postmodernism: A Marxist Critique. Cambridge: Polity.

[216] Callinicos, A. (1993) 'What is Living and What is Dead in the Philosophy of Althusser?' In Kaplan, E. and Sprinker, M. (eds).

[217] Cambridge Women's Studies Group (eds) (198 1) Women in Society: Interdisciplinary Essays. London: Virago.

[218] Chappell, V. C. (ed.) (1968) Hume. London: Macmillan.

[219] Chodorow, N. J. (1978) The Reproduction of Mothering: Psychoanalysis and the Sociology of Gender. Berkeley, Calif.: University of California Press.

[220] Chodorow, N. J. (1986) 'Towards a Relational Individualism: The Mediation of Self through Psychoanalysis'. In Heller, T., Sosna, M. and Wellbery, D. with Davidson, A., Swidler, A. and Watt, I. (eds).

[221] Chomsky, N. (1980) Rules and Representation. Oxford: Blackwell.

[222] Cicourel, A. V. (1964) Method and Measurement in Sociology. London: Macmillan.

[223] Cicourel, A. V. (1973) Cognitive Sociology: Language and Meaning in Social Interaction. Harmondsworth: Penguin.

[224] Cicourel, A. V. (1 976) The Social Organisation of Juvenile Justice. 2nd edn. London: Heinemann.

[225] Cicourel, A. V. (1981) 'Notes on the Integration of Micro- and Macro-Levels of Analysis'. In Knorr-Cetina, K. and Cicourel, A. (eds).

[226] Cicourel, A. V. (1993) 'Aspects of Structural and Processual Theories of Knowledge'. In Calhoun, C., LiPuma, E. and Postone, M. (eds).

[227] Clammer, J. (1976) 'Wittgensteinianism and the Social Sciences'. Sociological Review 24(4): 775-791.

[228] Clark, J., Modgil, C. and Modgil, S. (eds) (1990) Anthony Giddens: Consensus and Controversy. Brighton: Falmer.

[229] Clark, S. (1991) 'The Annales Historians'. In Skinner, Q. (ed.). 
[230] Cleaver, H. (1979) Reading 'Capital' Politically. Brighton: Harvester.

[231] Cockburn, C. (1990) 'The Material of Male Power'. In Lovell, T. (ed.).

[232] Cohen, G. A. (1984) Karl Marx's Theory of History: A Defence. Oxford: Oxford University Press.

[233] Cohen, I. (1989) Structuration Theory: Anthony Giddens and the Constitution of Social Life. London: Macmillan.

[234] Coleman, J. S. (1990) Foundations of Social Theory. Cambridge, Mass.: Belknap.

[235] Collins, R. (1981) 'Micro-Translation as a Theory Building Strategy'. In Knorr- Cetina, K. and Cicourel, A. (eds).

[236] Collins, R. (ed.) (1984) Sociological Theory. San Francisco: Josey Bass.

[237] Cooke, M. (1994) Language and Reason: A Study of Habermas's Pragmatics. Cambridge, Mass.: MIT Press.

[238] Cooley, C. H. (1902) Human Nature and the Social Order. New York: Free Press.

[239] Coser, L. (1979) 'American Trends'. In Bottomore, T. and Nisbet, R. (eds).

[240] Coulter, J. (1979) The Social Construction of Mind: Studies in Ethnomethodology and Linguistic Philosophy. London: Macmillan.

[241] Coulter, J. (1983) Rethinking Cognitive Theory. London: Macmillan.

[242] Coulter, J. (ed.) (1990) Ethnomethodological Sociology. Aldershot: Edward Elgar.

[243] Coward, R. (1982) 'Sexual Politics and Psychoanalysis'. In Brunt, R. and Rowan, C. (eds).

[244] Craib, I. (1992) Anthony Giddens. London: Routledge.

[245] Crook, S., Pakulski, J. and Waters, M. (1992) Postmodernization: Change in Advanced Society. London: Sage.

[246] Crosland, M. (1992) Simone de Beauvoir: The Woman and her Work. London: Heinemann.

[247] Crowley, H. and Himmelweit, S. (eds) (1992) Knowing Women: Feminism and Knowledge. Cambridge: Polity.

[248] Dahrendorf, R. (1959) Class and Class Conflict in Industrial Society. London: Routledge \& Kegan Paul.

[249] Davis, K., Leijenaar, M. and Oldersma, J. (eds) (1991) The Gender ofpower. London: Sage.

[250] Dawe, A. (1970) 'The Two Sociologies'. British Journal of Sociology, 21: 207-218.

[251] Dean, M. (1994) Critical and Effective Histories: Foucault's Methods and Historical Sociology. London: Routledge.

[252] Dean, M. (2006) Governing Societies: Dilemmas, Diagnoses, Departures Maidenhead, Open University Press.

[253] de Beauvoir, S. (1972) The Second Sex. Originally published in 1949. Harmondsworth: Penguin. 
[254] de Lauretis, T. (1990) 'Upping the Anti [sic] in Feminist Theory'. In Hirsch, M. and Fox Keller, E. (eds).

[255] Delmar, R. (1976) 'Looking Again at Engels' "Origin of the Family, Private Property and the State" '. In Oakley, A. and Mitchell, J. (eds).

[256] Delphy, C. and Leonard, D. (1992) Familiar Exploitation: A New Analysis of Marriage in Contemporary Western Society. Cambridge: Polity.

[258] Denzin, N. K. (1974) 'Symbolic Interactionism and Ethnomethodology7. In Douglas, J. D. (ed.).

[258] Denzin, N. K. (1992) Symbolic Interactionism and Cultural Studies: The Politics of Interpretation. Oxford: Blackwell.

[259] Derrida, J. (1978) Writing and Difference. London: Routledge.

[260] Dewey, J. (1896) 'The Reflexive Arc Concept in Psychology'. Psychological Review 3: $357-370$.

[261] Dews, P. (1989) 'The Return of the Subject in the Late Foucault'. Radical Philosophy 51: 37-41.

[262] Dews, P. (ed.) (1992) Autonomy and Solidarity: Interviews with Jurgen Habermas. Revised edn. London: Verso.

[263] Diamond, I. and Quinby, L. (eds) (1988) Feminism and Foucault: Reflections on Resistance. Boston, Mass.: Northeastern University Press.

[264] Ditton, J. (ed.) (1980) The View from Goffman. London: Macmillan.

[265] Docherty, T. (ed.) (1993) Postmodernism: A Reader. London: Harvester Wheatsheaf.

[266] Doney, W. (ed.) (1967) Descartes: A Collection of Critical Essays. London: Macmillan.

[267] Dore, R. P. (1973) 'Function and Cause'. In Ryan, A. (ed.).

[268] Douglas, J. D. (ed.) (1974) Understanding Everyday Life: Towards the Reconstruction of Sociological Knowledge. London: Routledge \& Kegan Paul.

[269] Douglas, M. (1970) Purity and Danger: An Analysis of the Concepts of Pollution and Taboo. New York: Pantheon.

[270] Douglas, M. (1978) Implicit Meanings: Essays in Anthropology. London: Routledge \& Kegan Paul.

[271] Drew, P. and Wootton, A. (eds) (1988) Erving Goffman: Exploring the Interaction Order. Cambridge: Polity.

[272] Dreyfus, H. and Rabinow, P. (1982) Michel Foucault: Beyond Structuralism and Hermeneutics. Chicago: University of Chicago Press.

[273] Dreyfus, H. and Rabinow, P. (1 993) 'Can There be a Science of Existential Structure and Social Meaning?' In Calhoun, C., LiPuma, E. and Postone, M. (eds).

[274] Du Bois, W. (1989) The Souls of Black Folk. Originally published in 1903. New York: Bantam.

[275] Durkheim, E. (1964) The Division of Labour in Society. Originally published in 1893. Translated by Simpson, G. New York: Free Press. 
[276] Durkheim, E. (1983) Pragmatism and Sociology. Originally published in 1955. Edited by Allcock, J. B. Translated by Whitehouse, J. C. Cambridge: Cambridge University Press.

[277] Durkheim, E. (1992) 'Review Chapter on F. S. Merlino's "Formes et essences du socialisme". Originally published in 1899. In Gane, M. (ed.).

[278] Dworkin, A. (1987) Intercourse. London: Secker \& Warburg.

[279] Easthope, A. and McGowan, K. (eds) (1992) A Critical and Cultural Theory Reader. Milton Keynes: Open University Press.

[280] Eco, U. (1993) 'The City of Robots'. In Docherty, T. (ed.).

[281] Elders, F. (ed.) (1974) Reflexive Waters: The Basic Concerns of Mankind. London: Souvenir.

[282] Elias, N. (1991) The Symbol Theory. London: Sage.

[283] Elliott, A. (1992) Social Theory and Psychoanalysis in Transition: Self and Society from Freud to Kristeva. Oxford: Blackwell.

[284] Engels, F. (1942) The Origin of the Family, Private Property and the State. Originally published in 1884. New York: International Publishers.

[285] Estes, C., Biggs, S and Phillipson, C. (2003) Social Theory, Aging and Social Policy, Milton Keynes: OUP.

[286] Evans, M. (ed.) (1982) The Woman Question: Readings on the Subordination of Women. London: Fontana.

[287] Faberman, H. A. (1985) 'The Foundations of Symbolic Interactionism: James, Cooley and Mead'. Reprinted in Plummer, K. (ed.) (1991a).

[288] Fairclough, N. (1989) Language and Power. London: Longman.

[289] Farganis, S. (1994) Situating Feminism: From Thought to Action. London: Sage.

[290] Featherstone, M. (ed.) (1991) Consumer Culture and Postmodernism. London: Sage.

[291] Featherstone, M. and Turner, B. (1995) 'Body and Society: An Introduction'. Body and Society 1(1): 1-12.

[292] Figes, E. (1978) Patriarchal Attitudes: Women in Society. Originally published in 1970. London: Virago.

[293] Firestone, S. (1988) The Dialectic of Sex: The Case for Feminist Revolution. Originally published 1970. London: Women's Press.

[294] Fisher, B. M. and Strauss, A. L. (1978) 'The Chicago Tradition and Social Change: Thomas, Park and their Successors'. Reprinted in Plummer, K. (ed.) (1991a).

[295] Fisher, B. M. and Strauss, A. L. (1979) 'Interactionism'. In Bottomore, T. and Nisbet, R. (eds).

[296] Foucault, M. (1979) The History of Sexuality, Volume 1: An Introduction. Translated by Hurley, R. Harmondsworth: Penguin.

[297] Foucault, M. (1980) PowerlKnowledge, Selected Interviews and Other Writings 19721977. Edited by Gordon, C. Brighton: Harvester. 
[298] Foucault, M. (1982) 'The Subject and Power'. In Dreyfus, H. and Rabinow, P. (eds).

[299] Foucault, M. (1984) The Foucault Reader. Edited by Rabinow, P. Harmondsworth: Penguin.

[300] Foucault, M. (1988a) 'The Political Technology of Individuals'. In Martin, L. H., Gutman, H. and Hutton, P. H. (eds).

[301] Foucault, M. (1988b) 'Technologies of the Self'. In Martin, L. H., Gutman, H. and Hutton, P. H. (eds).

[302] Foucault, M. (1988 'T) ruth, Power, Self: An Interview'. In Martin, L. H., Gutman, H. and Hutton, P. H. (eds).

[303] Foucault, M. (1989) The Archaeology of Knowledge. Originally published in 1969. London: Routledge.

[304] Foucault, M. (1991a) Remarks on Marx: Conversations with Duccio Trombadori. Translated by Goldstein, R. J. and Cascaito, J. New York: Semiotext(e).

[305] Foucault, M. (1991b) 'The Ethic of Care for the Self as a Practice of Freedom: An interview with Fornet-Betancourt, R., Becker, H. and Gomez-Miiller, A. Translated by Gauthier Snr, J. D. In Bernauer, J. and Rasmussen, D. (eds).

[306] Foucault, M. (1991) Questions of Method'. In Burchell, G., Gordon, C. and Miller, P. (eds).

[307] Foucault, M. (1991d) Discipline and Punish: The Birth of the Prison. Originally published in 1977. Translated by Sheridan, A. Harmondsworth: Penguin.

[308] Foucault, M. (1992) The Order of Things: An Archaeology of the Human Sciences. Originally published in 1970. London: Routledge.

[309] Fraser, N. (1989) Unruly Practices: Power, Discourse and Gender in Contemporary Social Theory. Cambridge: Polity.

[310] Freeman, J. (ed.) (1979) Women: A Feminist Perspective. 2nd edn. Palo Alto, Calif.: May field.

[311] Freud, S. (1938) Psychopathology of Everday Life. Harmondsworth: Penguin.

[312] Freud, S. (1969) Civilization and its Discontents. Translated by Riviere, J. Edited by Strachey, J. London: Hogarth.

[313] Freund, J. (1979) 'German Sociology in the Time of Max Weber'. In Bottomore, T. and Nisbet, R. (eds).

[314] Freundlieb, D. (1994) 'Foucault's Theory of Discourse and Human Agency'. In Jones, C. and Porter, R. (eds).

[315] Friedan, B. (1965) The Feminine Mystique. Harmondsworth: Penguin.

[316] Frisby, D. (1991) 'The Aesthetics of Modern Life: Simmel's Interpretation'. In Featherstone, M. (ed.).

[317] Frisby, D. (1992a) Sociological Impressionism: A Reassessment of Georg Simmel's Social Theory. 2nd edn. London: Routledge.

[318] Frisby, D. (1992b) Simmel and Since: Essays on Georg Simmel's Social Theory. London: Routledge. 
[319] Fromm, E. (1969) Escape from Freedom. Originally published in 1941. New York: Avon.

[320] Gadamer, H. G. (1975) Truth and Method. Originally published in 1960. London: Sheed \& Ward.

[321] Gane, M. (1990) 'Ironies of Postmodernism: Fate of Baudrillard's Fatalism'. Economy and Society 19(3): 314-334.

[322] Gane, M. (1991) Baudrillard: Critical and Fatal Theory. London: Routledge.

[323] Gane, M. (ed.) (1992) The Radical Sociology of Durkheim and Mauss. London: Routledge.

[324] Gane, M. (ed.) (1993) Baudrillard Live: Selected Interviews. London: Routledge.

[325] Garfinkel, H. (1967) Studies in Ethnomethodology. Englewood Cliffs, NJ: PrenticeHall.

[326] Garfinkel, H. (1974) 'The Origins of the Term "Ethnomethodology"'. Originally published in 1968. Reprinted in Turner, R. (ed.).

[327] Garfinkel, H. (ed.) (1986) Ethnomethodological Studies of Work. London: Routledge \& Kegan Paul.

[328] Garfinkel, H. (1991) 'Respecification: Evidence for Locally Produced, Naturally Accountable Phenomena of Order, Logic, Reason, Meaning, Method, etc. In and as of the Essential Haecceity of Immortal Ordinary Society, (1) - An Announcement of Studies'. In Button, G. (ed.).

[329] Garfinkel, H. and Sacks, H. (1986) 'On Formal Structures of Practical Actions'. In Garfinkel, H. (ed.).

[330] Gartman, D. (1991) 'Culture as Class Symbolization or Mass Reification? A Critique of Bourdieu's Distinction'. American lournal of Sociology 97(2): 421- 447.

[331] Gellner, E. (1968) Words and Things. Penguin: Harmondsworth.

[332] Gellner, E. (1974) 'The New Idealism: Cause and Meaning in the Social Sciences'. In Giddens, A. (ed.).

[333] Gellner, E. (1988) Culture, Identity and Politics. Cambridge: Cambridge University Press.

[334] Gellner, E. (1992) Reason and Culture: The Historic Role of Rationality and Rationalism. Oxford: Blackwell.

[335] Gerth, H. and Mills, C. W. (eds) (1970) From Max Weber: Essays in Sociology. Originally published in 1948. London: Routledge \& Kegan Paul.

[336] Giddens, A. (1 971) Capitalism and Modern Social Theory: An Analysis of the Writings of Marx, Durkheim and Max Weber. Cambridge: Cambridge University Press.

[337] Giddens, A. (1972a) Politics and Sociology in the Thought of Max Weber. London: Macmillan.

[338] Giddens, A. (ed.) (1972b) Emile Durkheim: Selected Writings. Cambridge: Cambridge University Press.

[339] Giddens, A. (ed.) (1974) Positivism and Sociology. London: Heinemann. 
[340] Giddens, A. (1976) New Rules of Sociological Method: A Positive Critique of Interpretive Sociologies. London: Hutchinson.

[341] Giddens, A. (1977) Studies in Social and Political Theory. London: Hutchinson.

[342] Giddens, A. (1979) Central Problems in Social Theory: Action, Structure and Contradiction in Social Analysis. London: Macmillan.

[343] Giddens, A. (1981a) A Contemporary Critique of Historical Materialism: Volume 1: Power, Property and the State. London: Macmillan.

[344] Giddens, A. (1981b) 'Agency, Institution, and Time-Space Analysis'. In Knorr-Cetina, K. and Cicourel, A. (eds).

[345] Giddens, A. (1982) Profiles and Critiques in Social Theory. Berkeley, Calif.: University of California Press.

[346] Giddens, A. (1984) The Constitution of society: Outline of the Theory of Structuration. Cambridge: Polity.

[347] Giddens, A. (1985) The Nation-State and Violence: Volume 2 of A Contemporary Critique of Historical Materialism. Cambridge: Polity.

[348] Giddens, A. (1987) Social Theory and Modern Sociology. Cambridge: Polity.

[349] Giddens, A. (1989) 'A Reply to my Critics'. In Held, D. and Thompson, J. B. (eds).

[350] Giddens, A. (1990) The Consequences of Modernity. Cambridge: Polity.

[351] Giddens, A. (1991a) 'Structuration Theory: Past, Present and Future'. In Bryant, C. and Jary, D. (eds).

[352] Giddens, A. (1991b) Modernity and Self-Identity. Cambridge: Polity.

[353] Giddens, A. (1992) The Transformation of Intimacy: Sexuality, Love and Eroticism in Modern Societies. Cambridge: Polity.

[354] Giddens, A. (1993) New Rules of Sociological Method: A Positive Critique of Interpretive Sociologies. 2nd edn. Cambridge: Polity.

[355] Giddens, A. (1994) Beyond Left and Right: The Future of Radical Politics. Cambridge: Polity.

[356] Giddens, A. and Turner, J. (eds) (1990) Social Theory Today. Cambridge: Polity.

[357] Gjertsen, D. (1992) Science and Philosophy: Past and Present. Harmondsworth: Penguin.

[358] Gliicksmann, A. (1992) 'Michel Foucault's Nihilism'. In Armstrong, T. (ed.).

[359] Goffman, E. (1961) Encounters: Two Studies in the Sociology of Interaction. Harmondsworth: Penguin.

[360] Goffman, E. (1968) Asylums: Essays on the Social Situation of Mental Patients and Other Inmates. Originally published in 1961. Harmondsworth: Penguin.

[361] Goffman, E. (1971) Relations in Public: Microstudies of the Public Order. Harmondsworth: Penguin.

[362] Goffman, E. (1972) Interaction Ritual: Essays on Face-to-Face Behaviour. Harmondsworth: Penguin. 
[363] Goffman, E. (1974) Frame Analysis: An Essay on the Organization of Experience. New York: Harper \& Row.

[364] Goffman, E. (1979) Gender Advertisements. London: Macmillan.

[365] Goffman, E. (1981) Forms of Talk. Philadelphia, Pa: University of Pennsylvania Press.

[366] Goffman, E. (1983) 'The Interaction Order'. The 1982 American Sociological Association Presidential Address. Reprinted in Plummer, K. (ed.) (1991 b).

[367] Goffman, E. (1984) The Presentation of Self in Everyday Life. Originally published in 1959. Harmondsworth: Penguin.

[368] Goldthorpe, J. H. (1973) 'A Revolution in Sociology?' Sociology 7: 449462. Goldthorpe, J. H. and Marshall, G. (1992) 'The Promising Future of Class Analysis'. Sociology 26(3): 381400.

[369] Gordon, C. (1987) 'The Soul of the Citizen: Max Weber and Michel Foucault on Rationality and Government'. In Lash, S. and Whimster, S. (eds).

[370] Gouldner, A. (1971) The Coming Crisis in Western Sociology. London: Heinemann.

[371] Gramsci, A. (1971) Prison Notebooks: Selections. Translated by Hoare, Q. and Smith, G. N. New York: International Publishers.

[372] Greer, G. (1970) The Female Eunuch. London: MacGibbon \& Kee.

[373] Gregson, N. (1989) 'On the (1r)relevance of Structuration Theory to Empirical Research'. In Held, D. and Thompson, J. B. (eds).

[374] Griffiths, M. (1988) 'Feminism, Feelings and Philosophy'. In Griffiths, M. and Whitford, M. (eds).

[375] Griffiths, M. and Whitford, M. (eds) (1988) Feminist Perspectives in Philosophy. London: Macmillan.

[376] Grimshaw, J. (1989) 'Mary Wollstonecraft and the Tensions in Feminist Philosophy'. Radical Philosophy 52: 11-17.

[377] Gross, E. (1992) 'What is Feminist Theory?' In Crowley, H. and Himmelweit, S. (eds).

[378] Grosz, E. (1990) 'A Note on Essentialism and Difference'. In Gunew, S. (ed.).

[379] Gunew, S. (ed.) (1990) Feminist Knowledge: Critique and Construct. London: Routledge.

[380] Habermas, J. (1975) Legitimation Crisis. Translated by McCarthy, T. Boston, Mass.: Beacon.

[381] Habermas, J. (1981) 'Towards a Reconstruction of Historical Materialism'. In KnorrCetina, K. and Cicourel, A. (eds).

[382] Habermas, J. (1984) Theory of Communicative Action. Volume 1: Reason and the Rationalization of Society. Translated by McCarthy, T. London: Heinemann.

[383] Habermas, J. (1986) 'Taking Aim at the Heart of the Present'. In Hoy, D. C. (ed.).

[384] Habermas, J. (1987) Theory of Communicative Action. Volume 2: Lifeworld and System: A Critique of Functionalist Reason. Translated by McCarthy, T. Cambridge: Polity. 
[385] Habermas, J. (1989a) Knowledge and Human Interests. Originally published in 1968. Translated by Shapiro, J. J. Cambridge: Polity.

[386] Habermas, J. (1989b) The Structural Transformation of the Public Sphere. Translated by Berger, T. and Lawrence, F. Cambridge, Mass.: MIT Press.

[387] Habermas, J. (1990) On the Logic of the Social Sciences. Originally published in 1970. Translated by Nicholsen, S. W. and Stark, J. A. Cambridge: Polity.

[388] Habermas, J. (1991) 'A Reply'. In Honneth, A. and Joas, H. (eds).

[389] Habermas, J. (1992a) The Philosophical Discourse of Modernity: Twelve Lectures. Cambridge: Polity.

[390] Habermas, J. (1992b) Postmetaphysical Thinking: Philosophical Essays. Translated by Hohengarten, W. M. Cambridge, Mass.: MIT Press.

[391] Habermas, J. (1992 M) oral Consciousness and Communicative Action. Translated by Lenhardt, C. and Nicholsen, S. Introduction by McCarthy, T. Cambridge: Polity.

[392] Habermas, J. (1993) Justification and Application: Remarks on Discourse Ethics. Translated by Cronin, C. Cambridge: Polity.

[393] Habermas, J. (1994) The Past as Future. Interviewed by Haller, M. Translated and edited by Pensky, M. Cambridge: Polity.

[394] Habermas, J. (1996) Between Facts and Norms: Contributions to a Discourse Theory of Law and Democracy. Cambridge: Polity.

[395] Hage, J. (ed.) (1994) Formal Theory in Sociology: Opportunity or Pitfall? Albany.

[396] Hall, P. M. (1987) 'Interactionism and the Study of Social Organization'. Reprinted in NY: State University of New York Press.

[397] Hall, S. and Gieben, B. (eds) (1992) Formations of Modernity. Polity Press in association with the Open University. Cambridge: Polity.

[398] Hamilton, P. (1983) Talcott Parsons. London: Tavistock.

[399] Hamilton, P. (ed.) (1985) Readings from Talcott Parsons. London: Tavistock.

[400] Hamilton, P. (1992) 'The Enlightenment and the Birth of Social Science'. In Hall, S. and Gieben, B. (eds).

[401] Haraway, D. (1991) Simians, Cyborgs, and Women: The Reinvention of Nature. New York: Routledge.

[402] Harding, S. (1986) The Science Question in Feminism. Milton Keynes: Open University Press.

[403] Harding, S. (1991) Whose Science? Whose Knowledge? Thinking from Women's Lives. Milton Keynes: Open University Press.

[404] Harding, S. and Hintikka, M. B. (1983a) 'Introduction'. In Harding, S. and Hintikka, M. B. (eds).

[405] Harding, S. and Hintikka, M. B. (eds) (1983b) Discovering Reality: Feminist Perspectives on Epistemology, Metaphysics, Methodology, and Philosophy of Science. London: D. Reidel. 
[406] Hartsock, N. (1983) 'The Feminist Standpoint: Developing the Ground for a Specifically Feminist Historical Materialism'. In Harding, S. and Hintikka, M. B. (eds).

[407] Harvey, D. (1990) The Condition of Postmodernity: An Enquiry into the Origins of Cultural Change. Oxford: Blackwell.

[408] Hawthorn, G. (1976) Enlightenment and Despair: A History of Sociology. Cambridge: Cambridge University Press.

[409] Hearn, J. and Morgan, D. (eds) (1990) Men, Masculinities and Social Theory. London: Unwin Hyman.

[410] Hearnshaw, F. J. C. (ed.) (1967) The Social and Political Ideas of Some Representative Thinkers of the Age of Reaction and Reconstruction: 1815-1865. Originally published in 1932. London: Dawsons.

[411] Hegel, G. W. F. (1967a) The Phenomenology of Mind. Translated by Baillie, J. B. Oxford: Oxford University Press.

[412] Hegel, G. W. F. (1967b) Hegel's Philosophy of Right. Translated by Knox, T. M. Oxford: Oxford University Press.

[413] Heilbron, J. (1995) The Rise of Social Theory. Translated by Gogol, S. Cambridge: Polity.

[414] Hekman, S. (1990a) 'Hermeneutics and the Crisis of Social Theory: A Critique of Giddens's Epistemology'. In Clark, J., Modgil, C. and Modgil, S. (eds).

[415] Hekman, S. (1990b) Gender and Knowledge: Elements of a Postmodern Feminism. Cambridge: Polity.

[416] Held, D. (1990) introduction to Critical Theory: Horkheimer to Habermas. Cambridge: Polity.

[417] Held, D. and Thompson, J. (eds) (1989) Social Theory of Modern Societies: Anthony Giddens and his Critics. Cambridge: Cambridge University Press.

[418] Heller, A. (1984) Everyday Life. Translated by Campbell, G. London: Routledge \& Kegan Paul.

[419] Heller, A. and FehCr, F. (1991) The Postmodern Political Condition. Cambridge: Polity.

[420] Heller, T., Sosna, M. and Wellbery, D. with Davidson, A., Swidler, A. and Watt, I. (eds) (1986) Reconstructing individualism: Autonomy, individuality, and the Self in Western Thought. Stanford, Calif.: Stanford University Press.

[421] Heritage, J. (1984) Garfinkel and Ethnomethodology. Cambridge: Polity.

[422] Heritage, J. (1990) 'Ethnomethodology'. In Giddens, A. and Turner, J. (eds).

[423] Hill, R. J. and Stones Crittenden, K. (eds) (1968) 'Proceedings of the Purdue Symposium on Ethnomethodology'. Purdue University: Institute for the Study of Social Change, Department of Sociology.

[424] Hindness, B. (1996) Discourses of Power: From Hobbes to Foucault. Oxford: Blackwell.

[425] Hirsch, M. and Fox Keller, E. (eds) (1990) Conflicts in Feminism. London: Routledge. 
[426] Hole, J. and Levine, E. (1979) 'The First Feminists'. In Freeman, J. (ed.).

[427] Hollingdale, R. J. (ed.) (1977) A Nietzsche Reader. Translated by Hollingdale, R. J. Harmondsworth: Penguin.

[428] Hollis, M. and Lukes, S. (eds) (1982) Rationality and Relativism. Oxford: Blackwell.

[429] Holton, R. and Turner, B. (1990) Max Weber on Economy and Society. London: Routledge.

[430] Holtzman, S. and Leich, C. (eds) (1981) Wittgenstein: To Follow a Rule. London: Routledge \& Kegan Paul.

[431] Holub, R. C. (1991) Jurgen Habermas: Critic in the Public Sphere. London: Routledge.

[432] Homans, G. (1961) Social Behaviour: Its Elementary Forms. New York: Harcourt Brace Jovanovich.

[433] Homans, G. (1973) 'Bringing Men Back In'. In Ryan, A. (ed.).

[434] Honneth, A. (1991) The Critique of Power: Reflective Stages in a Critical Social Theory. Translated by Baynes, K. Cambridge, Mass.: MIT Press.

[435] Honneth, A. (1993) 'Critical Theory in Germany Today: An Interview'. Radical Philosophy 65: 33-41.

[436] Honneth, A. and Joas, H. (1988) Social Action and Human Nature. Cambridge: Cambridge University Press.

[437] Honneth, A. and Joas, H. (eds) (1991) Communicative Action: Essays on Habermas's 'The Theory of Communicative Action'. Translated by Gains, J. and Jones, D. L. Cambridge, Mass.: MIT Press.

[438] Honneth, A., McCarthy, M., Offe, C. and Wellmer, A. (eds) (1992) Cultural-Political Interventions in the Unfinished Project of Enlightenment. Cambridge, Mass.: MIT Press.

[439] Horkheimer, M. (1993) Between Philosophy and Social Science: Selected Early Writings. Translated by Hunter, G. F., Kramer, M. S. and Torpey, J. Cambridge, Mass.: MIT Press.

[440] Houtkoop-Steenstra, H. (1993) 'Opening Sequences in Dutch Telephone Conversations'. In Boden, D. and Zimmerman, D. H. (eds).

[441] Hoy, D. C. (1986a) 'Power, Repression, Progress: Foucault, Lukes, and the Frankfurt School'. In Hoy, D. C. (ed.).

[442] Hoy, D. C. (ed.) (1986b) Foucault: A Critical Reader. Oxford: Blackwell.

[443] Hoy, D. C. and McCarthy, T. (1994) Critical Theory. Oxford: Blackwell.

[444] Hughes, E. (1971) The Sociological Eye: Selected Books. Chicago: Aldine-Atherton.

[445] Hughes, S. H. (1979) Consciousness and Society: The Reorientation of European Social Thought 2 890-1 930. Brighton: Harvester.

[446] Humm, M. (ed.) (1992) Feminisms: A Reader. London: Harvester Wheatsheaf.

[447] Jaggar, A. (1983) Feminist Politics and Human Nature. London: Harvester. 
[448] James, W. (1890) Principles of Psychology. 2 volumes. New York: Holt.

[449] Jameson, F. (1992) Postmodernism, or, The Cultural Logic of Late Capitalism. London: Verso.

[450] Jay, M. (1973) The Dialectical Imagination: A History of the Frankfurt School and the Institute of Social Research 1923-2 950. London: Heinemann.

[451] Joas, H. (1985) G. H. Mead: A Contemporary Re-Examination of his Thought. Translated by Meyer, R. Cambridge: Polity.

[452] Joas, H. (1993) Pragmatism and Social Theory. Chicago: University of Chicago Press.

[453] Johnson, L. C. (1990) 'Socialist Feminisms'. In Gunew, S. (ed.).

[454] Johnson, P. (1993) 'Feminism and the Enlightenment'. Radical Philosophy 63: 3-12.

[455] Johnson, T., Dandeker, C. and Ashworth, C. (1984) The Structure of Social Theory: Dilemmas and Strategies. London: Macmillan.

[456] Jones, C. (1992) 'Reason without Emotion'. Radical Philosophy 61: 32-33.

[457] Jones, C. and Porter, R. (eds) (1994) Reassessing Foucault: Power, Medicine and the Body. London: Routledge.

[458] Kamuf, P. (ed.) (1991) A Derrida Reader: Between the Blinds. London: Harvester Wheatsheaf.

[459] Kaplan, E. A. and Sprinker, M. (eds) (1993) The Althusserian Legacy. London: Verso.

[460] Keat, R. and Urry, J. (1975) Social Theory as Science. London: Routledge \& Kegan Paul.

[461] Kellner, D. (1993) 'Popular Culture and the Construction of Postmodern Identities'. In Lash, S. and Friedman, J. (eds).

[462] Kellner, D. (ed.) (1994) Baudrillard: A Critical Reader. Oxford: Blackwell.

[463] Kelly, M. (ed.) (1994) Critique and Power: Recasting the Foucault-Haberrnas Debate. Cambridge, Mass.: MIT Press.

[464] Kinnaird, J. K. (1983) 'Mary Astell: Inspired by Ideas'. In Spender, D. (ed.).

[465] Klein N (2001) NoLogo, London, Flamingo.

[466] Knorr-Cetina, K. (1981) 'The Micro-Sociological Challenge of Macro-Sociology: Towards a Reconstruction of Social Theory and Methodology'. In Knorr-Cetina, K. and Cicourel, A. (eds).

[467] Knorr-Cetina, K. and Cicourel, A. (eds) (1981) Advances in Social Theory and Methodology: Towards an Integration of Micro and Macro Theories. London: Routledge \& Kegan Paul.

[468] Kolakowski, L. (1978a) Main Currents of Marxism, Volume 2 . Oxford: Oxford University Press.

[469] Kolakowski, L. (1978b) Main Currents of Marxism, Volume 2. Oxford: Oxford University Press. 
[470] Kortian, G. (1 980) Metacritique: The Philosophical Argument of Jiirgen Habermas. Translated by Raffan, J. Cambridge: Cambridge University Press.

[471] Kroker, A. and Cook, D. (1988) The Postmodern Scene: Excremental Culture and Hyper-Aesthetics. London: Macmillan.

[472] Kurtz, L. (1984) Evaluating Chicago Sociology: A Guide to the Literature with an Annotated Bibliography. Chicago: Chicago University Press.

[473] Laclau, E. and Mouffe, C. (1990) Hegemony and Socialist Strategy: Towards a Radical Democratic Politics. Third impression. London: Verso.

[474] Landry, D. and MacLean, G. (1993) Materialist Feminisms. Oxford: Blackwell.

[475] Larrabee, M. J. (ed.) (1993) An Ethic of Care: Feminist and Interdisciplinary Perspectives. London: Routledge.

[476] Lash, S. (1990) The Sociology of Postmodernism. London: Routledge.

[477] Lash, S. (1993) 'Pierre Bourdieu: Cultural Economy and Social Change'. In Calhoun, C., LiPuma, E. and Postone, M. (eds).

[478] Lash, S. and Friedman, J. (eds) (1993) Modernity and Identity. Oxford: Blackwell.

[479] Lash, S. and Urry, J. (1987) The End of Organized Capitalism. Cambridge: Polity.

[480] Lash, S. and Urry, J. (1994) Economies of Signs and Space. London: Sage.

[481] Lash, S. and Whimster, S. (eds) (1987) Max Weber, Rationality and Modernity. London: Allen \& Unwin.

[482] Laslett, P. and Runciman, W. G. (eds) (1967) Philosophy, Politics and Society. Oxford: Oxford University Press.

[483] Latour, B. (1986) 'The powers of association' in Law, J. (ed) Power, Action and Belief: A New Sociology of Knowledge? London, Routledge

[484] Law, J. (1986) 'On power and its tactics: a view from the sociology of science' The Sociological Review 34(1): 1-38

[485] Law, J. and Hassard, J. (eds) (1999) Actor Network Theory and After Oxford, Blackwell

[486] Lawler, S. (1995) 'Mothering the Self: A Study of the Mother-Daughter Relationship'. Unpublished Ph.D. Centre for Women's Studies, Department of Sociology, University of Lancaster.

[487] Layder, D. (1987) 'Key Issues in Structuration Theory: Some Critical Remarks'. Current Perspectives in Social Theory 8: 25-46.

[488] Layder, D. (2004) Emotion in Social Life. London Sage.

[489] Layder, D. (2006) Understanding Social Theory, (2nd edition). London: Sage.

[490] Leeds Revolutionary Feminist Group (1982) 'Political Lesbianism: The Case against Heterosexuality'. In Evans, M. (ed.) .

[491] Lemert, C. (1979) 'De-Centred Analysis: Ethnomethodology and Structuralism'. Theory and Society 7: 289-306. 
[492] Lemert, C. (ed.) (1993) Social Theory: The Multicultural and Classic Readings. Oxford: Westview.

[493] Lemert, C (2006) Social Things. Lanham: Rowman and Littlefield

[494] Levi-Strauss, C. (1963) Structural Anthropology. New York: Basic Books.

[495] Lewis, J. D. and Smith, R. L. (1980) American Sociology and Pragmatism: Mead, Chicago Sociology and Symbolic Interactionism. Chicago: University of Chicago Press.

[496] Lincourt, J. M. and Hare, P. H. (1973) 'Neglected American Philosophers in the History of Symbolic Interactionism'. Reprinted in Plummer, K. (ed.) (1991 a).

[497] Lindsay, A. D. (1967) 'Hegel the German Idealist'. In Hearnshaw, F. J. C. (ed.).

[498] Lockwood, D. (1976) 'Social Integration and System Integration'. In Zollschan, G. K. and Hirsch, W. (eds).

[499] Lofland, J. (1976) Doing Social Life. New York: Wiley.

[500] Lovell, T. (ed.) (1990) British Feminist Thought: A Reader. Oxford: Blackwell.

[501] Lowith, K. (1993) Max Weber and Karl Marx. New edn. Preface by Turner, B. S. Edited with an introduction by Bottomore, T. and Outhwaite, W. London: Routledge.

[502] Luhmann, N. (1982) The Differentiation of Society. Translated by Holmes, S. and Larmore, C. New York: Columbia University Press.

[503] Luhmann, N. (1986) 'The Individuality of the Individual'. In Heller, T., Sosna, M. and Wellbery, D. with Davidson, A., Swidler, A. and Watt, I. (eds).

[504] Luhmann, N. (1993) Risk: A Sociological Theory. Translated by Barrett, R. New York: Walter de Gruyter.

[505] Lukiics, G. (1971) History and Class Consciousness: Studies in Marxist Dialectics. Originally published in 1923. London: Merlin.

[506] Lukes, S. (1967) 'Alienation and Anomie'. In Laslett, P. and Runciman, W. G. (eds).

[507] Lukes, S. (1973) 'Methodological Individualism Reconsidered'. In Ryan, A. (ed.).

[508] Lukes, S. (1981) Emile Durkheim: His Life and Work: A Historical and Critical Study. Harmondsworth: Penguin.

[509] Lukes, S. (1985) Marxism and Morality. Oxford: Oxford University Press.

[510] Lyman, S. (1991) Militarism, Imperialism and Racial Accommodation: An Analysis and Interpretation of the Early Writings of Robert E. Park. Fayetteville, Ark.: University of Arkansas Press.

[511] Lyon, D. (1994) The Electronic Eye: The Rise of Surveillance Society. Cambridge: Polity.

[512] Lyotard, J. F. (1984) The Postmodern Condition: A Report on Knowledge. Translated by Bennington, G. and Massumi, B. Foreword by Jameson, F. Manchester: Manchester University Press.

[513] Lyotard, J. F. (1993) 'Answering the Question: What is Postmodernism?' In Docherty, T. (ed.). 
[514] McCarthy, T. (1984) The Critical Theory of Jiirgen Habermas. Cambridge: Polity.

[515] McCarthy, T. (1991) 'Complexity and Democracy: Or the Seducements of Systems Theory'. In Honneth, A. and Joas, H. (eds).

[516] McHugh, P. (1974) 'On the Failure of Positivism'. In Douglas, J. D. (ed.).

[517] McHugh, P., Raffel, S., Foss, D. C. and Blum, A. F. (1974) On the Beginning of Social Inquiry. London: Routledge \& Kegan Paul.

[518] MacIntyre, A. (1973) 'The Idea of a Social Science'. In Ryan, A. (ed.)

[519] MacIntyre, A. (1985) After Virtue: A Study in Moral Theory. 2nd edn. London: Duckworth.

[520] MacKinnon, C. (1988) 'Desire and Power: A Feminist Perspective'. In Nelson, C. and Grossberg, L. (eds).

[521] McGrew, A (2007) 'Globalization in Hard Times: Contention in the Academy and Beyond.' In Ritzer, G (ed.), The Blackwell Companion to Globalization. Oxford: Blackwell.

[522] McLellan, D. and Sayers, S. (eds) (1990) Socialism and Morality. London: Macmillan.

[523] McLennan, G. (1995) Pluralism. Buckingham: Open University Press.

[524] McNay, L. (1994) Foucault: A Critical Introduction. Cambridge: Polity.

[525] McPhail, C. and Rexroat, C. (1979) 'Mead vs. Blumer: The Divergent Methodological Perspectives of Social Behaviourism and Symbolic Interactionism'. Reprinted in Plummer, K. (ed.) (1991a).

[526] Mannheim, K. (1952) Essays on the Sociology of Knowledge. Translated and edited by Kecskemeti, P. New York: Oxford University Press.

[527] Manning, P. (1992) Erving Goffman and Modern Sociology. Cambridge: Polity.

[528] Marcuse, H. (1966) Eros and Civilization: A Philosophical Inquiry into Freud. $2^{\text {nd }}$ edn. Boston, Mass.: Beacon.

[529] Marcuse, H. (1968a) One Dimensional Man: The Ideology of Industrial Society. London: Sphere.

[530] Marcuse, H. (1968b) Negations: Essays in Critical Theory. Boston, Mass.: Beacon.

[531] Marcuse, H. (1969) Reason and Revolution: Hegel and the Rise of Social Theory. London: Routledge \& Kegan Paul.

[532] Marshall, B. L. (1994) Engendering Modernity: Feminism, Social Theory and Social Change. Cambridge: Polity.

[533] Martin, J. R. (1994) 'Methodological Essentialism, False Difference, and Other Dangerous Traps'. Signs 19(3): 630-657.

[534] Martin, L. H., Gutman, H. and Hutton, P. H. (eds) (1988) Technologies of the Self: A Seminar with Michel Foucault. London: Tavistock.

[535] Marx, K. (1961) The Poverty of Philosophy. Originally published in 1847. Edited by Arthur, C. J. London: Lawrence \& Wishart.

[536] Marx, K. (1964) The German Ideology. London: Lawrence \& Wishart. 
[537] Marx, K. (1980) 'The Eighteenth Brumaire of Louis Bonaparte'. In Marx, K. and Engels, F.

[538] Marx, K. (1981) Economic and Philosophical Manuscripts of 1844. London: Lawrence \& Wishart.

[539] Marx, K. (1983) Capital: A Critique of Political Economy. Volume 2 : The Process of Production of Capital. Edited by Engels, F. Translated by Moore, S. and Aveling, E. English edition first published in 1887. London: Lawrence \& Wishart.

[540] Marx, K. and Engels, F. (1953) Selected Correspondence: 1843-2895. London: Lawrence \& Wishart.

[541] Marx, K. and Engels, F. (1970) The German Ideology. London: Lawrence \& Wishart.

[542] Marx, K. and Engels, F. (1980) Selected Works in One Volume. London: Lawrence \& Wishart.

[543] May, T (1996) Situating Social Theory, OUP

[544] Mayer, T. (1994) Analytical Marxism. London: Sage.

[545] Maynard, D. W. and Clayman, S. E. (1991) 'The Diversity of Ethnomethodology'. Annual Review of Sociology 17: 385-41 8.

[546] Mead, G. H. (1 9 10) 'What Social Objects Must Psychology Presuppose?' Reprinted in Reck, A. J. (ed.).

[547] Mead, G. H. (1930) 'Cooley's Contribution to American Social Thought'. Reprinted in Plummer, K. (ed.) (1991a).

[548] Meltzer, B. N. and Petras, J. W. (1973) 'The Chicago and Iowa Schools of Symbolic Interactionism'. In Shibutani, T. (ed.).

[549] Meltzer, B. N., Petras, J. W. and Reynolds, L. T. (1975) Symbolic Interactionism: Genesis, Varieties and Criticism. London: Routledge \& Kegan Paul.

[550] Mennell, S. (1975) 'Ethnomethodology and the New Methodenstreit'. Acta Sociologica 18(4): 287-302.

[551] Mennell, S. (1992) Norbert Elias: An Introduction. Oxford: Blackwell.

[552] Merton, R. (1968) Social Theory and Social Structure. New York: Free Press.

[553] Mestrovic S. (1992) The Coming Fin de Sidcle: An Application of Durkheim's Sociology to Modernity and Postmodernity. London: Routledge.

[554] Mestrovic, S. (1993) The Barbarian Temperament: Towards a Critical Postmodern Theory. London: Routledge.

[555] Milband, R. (1990) 'Class Analysis'. In Giddens, A. and Turner, J. (eds).

[556] Millett, K. (1969) Sexual Politics. New York: Avon.

[557] Millett, K. (1992) 'Beyond Politics? Children and Sexuality'. In Vance, C. S. (ed.).

[558] Mills, C. W. (1970) The Sociological Imagination. Originally published in 1959. Harmondsworth: Penguin.

[559] Mitchell, J. (1966) 'Women: The Longest Revolution'. New Left Review 40: 11-37. 
[560] Mitchell, J. (1 974) Woman's Estate. Harmondsworth: Penguin.

[561] Mitchell, J. (1986) 'Reflections on Twenty Years of Feminism'. In Mitchell, J. and Oakley, A. (eds).

[562] Mitchell, J. and Oakley, A. (eds) (1986) What is Feminism? Oxford: Blackwell.

[563] Moi, T. (1991) 'Appropriating Bourdieu: Feminist Theory and Pierre Bourdieu's Sociology of Culture'. New Literary History 22: 1017-1049.

[564] Mommsen, W. J. (1992) The Political and Social Theory of Max Weber: Collected Essays. Cambridge: Polity.

[565] Monk, R. (1990) Ludwig Wittgenstein: The Duty of Genius. London: Vintage.

[566] Mouzelis, N. (1991) Back to Sociological Theory: The Construction of Social Orders. London: Macrnillan.

[567] Mouzelis, N. (1995) Sociological Theory: What Went Wrong? Diagnoses and Remedies. London: Routledge.

[568] Mullan, B. (1987) Sociologists on Sociology: Interviews with Contemporary Sociologists. London: Croom Helm.

[569] Murgatroyd, L. (1989) 'Only Half the Story: Some Blinkering Effects of 'Malestream" Sociology'. In Held, D. and Thompson, J. B. (eds).

[570] Mythen, G and S. Walklate (2006) (eds) Beyond the Risk Society London: McGrawHill.

[571] Nelson, C. and Grossberg, L. (eds) (1988) Marxism and the Interpretation of Culture. London: Macmillan.

[572] Nisbet, R. (1970) The Sociological Tradition. London: Heinemann.

[573] Norris, C. (1987) Derrida. London: Fontana.

[574] Norris, C. (1996) Reclaiming Truth: Contribution to a Critique of Cultural Relativism. London: Lawrence \& Wishart.

[575] Nuyen, A. T. (1990) 'Truth, Method, and Objectivity: Husserl and Gadamer on Scientific Method'. Philosophy of the Social Sciences 20(4): 437452.

[576] Oakley, A. (1972) Sex, Gender and Society. London: Maurice Temple Smith.

[577] Oakley, A. (1974) The Sociology of Housework. Oxford: Martin Robertson.

[578] Oakley, A. and Mitchell, J. (eds) (1976) The Rights and Wrongs of Women. Harmondsworth: Penguin.

[579] O'Connor, J. (1987) The Meaning of Crisis: A Theoretical Introduction. Oxford: Blackwell.

[580] Offe, C. (1985) Disorganized Capitalism. Edited by Keane, J. Cambridge: Polity.

[581] Okin, S, M. (1980) Women in Western Political Thought. London: Virago.

[582] Ollman, B. (1979) Social and Sexual Revolution: Essays on Marx and Reich. London: Pluto.

[583] O'Neill, J. (1995) The Poverty of Postmodernism. London: Routledge. 
[584] Ortner, S. B. (1982) 'Is Female to Male as Nature is to Culture?' In Evans, M. (ed.).

[585] Osborn, R. (1937) Freud and Marx: A Dialectical Study. Introduction by Strachey, J. London: Gollancz.

[586] Outhwaite, W. (1975) Understanding Social Life: The Method Called 'Verstehen'. London: Allen \& Unwin.

[587] Outhwaite, W. (1994) Habermas. Cambridge: Polity.

[588] Owen, T. (2007) 'Genetic-social science and the study of human biotechnology', Current Sociology, 54 6: 897-917.

[589] Owen, T. and Powell, J.L. (2006) ''Trust', professional power and social theory: lessons from a post-Foucauldian framework', International Journal of Sociology and Social Policy, 26(3/4): 110-120.

[590] Paci, E. (1 972) The Function of the Sciences and the Meanings of Man. Translated by Piccone, P. and Hansen, J. Evanston, Ill.: Northwestern University Press.

[591] Park, R. E. (1936) 'Human Ecology'. American Journal of Sociology 42: 1-15.

[592] Park, R. E. (1972) The Crowd and the Public and Other Essays. Edited by Elsner, H. Translated by Elsner, C. Chicago: University of Chicago Press.

[593] Parsons, T. (1937) The Structure of Social Action. New York: McGraw-Hill.

[594] Parsons, T. (1951) The Social System. New York: Free Press.

[595] Parsons, T. (1965) 'An Outline of the Social System'. In Parsons, T., Shils, E., Naegele, K. D. and Pitts, J. R. (eds).

[596] Parsons, T., Shils, E., Naegele, K. D. and Pitts, J. R. (eds) (1965) Theories of Society: Foundations of Modern Sociological Theory. New York: Free Press.

[597] Pearce, F. (1989) The Radical Durkheim. London: Unwin Hyman.

[598] Petras, J. W. (1968) 'Psychological Antecedents of Sociological Theory in America: Williams James and James Mark Baldwin'. Reprinted in Plummer, K. (ed.) (1991a).

[599] Plamenatz, J. (1963) Man and Society: Volume 1: A Critical Examination of Some Important Social and Political Theories from Machiavelli to Marx. London: Longman.

[600] Plummer, K. (ed.) (1991 a) Symbolic Interactionism, Volume 1 : Foundations and History. Aldershot: Edward Elgar.

[601] Plummer, K. (ed.) (1991 b) Symbolic Interactionism, Volume 2: Contemporary Issues. Aldershot: Edward Elgar.

[602] Pollner, M. (1991) 'Left of Ethnomethodology: The Rise and Decline of Radical Reflexivity'. American Sociological Review 56(3): 370-380.

[603] Powell, J (2005) Social Theory and Aging. Lanham: Rowman and Littlefield

[604] Powell, J (2006) Rethinking Social Theory and Later Life. New York: Nova Science

[605] Powell, J (2006) Foucault and Aging. New York: Nova Science

[606] Powell, J and Owen, T (2007) Reconstructing Postmodernism. New York: Nova Science 
[607] Poulantzas, N. (1 978) State, Power, Socialism. Translated by Camiller, P. London: New Left Books.

[608] Ramazanoglu, C. (1990) Feminism and the Contradictions of Oppression. London: Routledge.

[609] Ramazanoglu, C. (ed.) (1993) Up against Foucault: Explorations of some Tensions between Foucault and Feminism. London: Routledge.

[610] Rattansi, A. (1 994) ' "Western" Racisms, Ethnicities and Identities in a " Postmodern" Frame'. In Rattansi, A. and Westwood, S. (eds).

[611] Rattansi, A. and Westwood, S. (1994a) 'Modern Racisms, Racialized Identities'. In Rattansi, A. and Westwood, S. (eds).

[612] Rattansi, A. and Westwood, S. (eds) (1994b) Racism, Modernity and Identity on the Western Front. Cambridge: Polity.

[613] Rawls, A. W. (1987) 'The Interaction Order Sui Generis: Goffman's Contribution to Social Theory. Sociological Theory 5 (2) : 13 6-149.

[614] Ray, L. and Reed, M. (eds) (1994) Organizing Modernity: New Weberian Perspectives on Work, Organization and Society. London: Routledge.

[615] Reck, A. J. (ed.) (1964) Selected Writings: George Herbert Mead. Chicago: University of Chicago Press.

[616] Rex, J. (1961) Key Problems of Sociological Theory. London: Routledge \& Kegan Paul.

[617] Rich, A. (1980) 'Compulsory Heterosexuality and Lesbian Existence'. Signs: Journalof Women in Culture and Society 5(4): 631-660.

[618] Ricoeur, P. (1982) Hermeneutics and the Human Sciences. Edited and translated by Thompson, J. B. Cambridge: Cambridge University Press.

[619] Risseeuw, C. (1991) 'Bourdieu, Power and Resistance: Gender Transformation in Sri Lanka'. In Davis, K., Leijenaar, M. and Oldersma, J. (eds).

[620] Ritzer, G (2004) The Globalization of Nothing. Thousand Oaks, CA: Pine Forge Press.

[621] Ritzer, G (2005) The McDonaldization of Society. Thousand Oaks, CA: Pine Forge Press.

[622] Ritzer, G (2006) Enchanting a Disenchanted World: Revolutionizing the Means of Consumption. Thousand Oaks, CA: Pine Forge Press.

[623] Robbins, D. (1991) The Work of Pierre Bourdieu: Recognizing Society. Milton Keynes: Open University Press.

[624] Robertson, R. and Turner, B. S. (eds) (1991) Talcott Parsons: Theorist of Modernity. London: Sage.

[625] Rocher, G. (1974) Talcott Parsons and American Sociology. Translated by Mennell, B. and Mennell, S. London: Thomas Nelson.

[626] Rock, P. (1979) The Making of Symbolic Interactionism. London: Macmillan.

[627] Rogers, K. M. (ed.) (1979) Before Their Time: Six Women Writers of the Eighteenth Century. New York: Frederick Unger. 
[628] Rogers, M. F. (1977) 'Goffman on Power'. American Sociologist 12(April): 88-95.

[629] Rogers, M. F. (1983) Sociology, Ethnomethodology, and Experience: A Phenomenological Critique. Cambridge: Cambridge University Press.

[630] Rogers, M. F. (1984) 'Everyday Life as Text'. In Collins, R. (ed.).

[631] Rorty, R. (1982) Consequences of Pragmatism: Essays 1972-1 980. Minneapolis, Minn.: University of Minneapolis Press.

[632] Rorty, R. (1 989) Contingency, Irony and Solidarity. Cambridge: Cambridge University Press.

[633] Rorty, R. (1993) 'Cosmopolitanism without Emancipation: A Response to Lyotard'. In Lash, S. and Friedman, J. (eds).

[634] Rose, A. (ed.) (1972) Human Behaviour and Social Processes: An Interactionist Approach. London: Routledge \& Kegan Paul.

[635] Rose, J. (1990) 'Femininity and its Discontents'. In Lovell, T. (ed.).

[636] Ross, D. (1991) The Origins of American Social Science. Cambridge: Cambridge University Press.

[637] Rowbotham, S. (1973) Woman's Consciousness, Man's World. Harmondsworth: Penguin.

[638] Rowland, R. and Klein, R. D. (1990) 'Radical Feminism: Critique and Construct'. In Gunew, S. (ed.).

[639] Rubinstein, D. (1981) Marx and Wittgenstein: Social Praxis and Social Explanation. London: Routledge \& Kegan Paul.

[640] Runciman, W. G. (1973) 'What is Structuralism?' In Ryan, A. (ed.).

[641] Russell, B. (1955) History of Western Philosophy and its Connection with Political and Social Circumstances from the Earliest Times to the Present Day. Fifth impression. London: Allen \& Unwin.

[642] Ryan, A. (ed.) (1973) The Philosophy of Social Explanation. Oxford: Oxford University Press.

[643] Ryan, A. (1986) Property and Political Theory. Oxford: Blackwell.

[644] Sacks, H. (1963) 'Sociological Description'. Berkeley Journal of Sociology 8: 1-16.

[645] Sacks, H. (1972) 'An Initial Investigation of the Usability of Conversational Data for Doing Sociology'. In Sudnow, D. (ed.).

[646] Sartre, J.-P. (1960) Critique of Dialectic Reason. London: New Left Books.

[647] Sarup, M. (1993) An Introductory Guide to Post-Structuralism and Postmodernism. 2nd edn. London: Harvester Wheatsheaf.

[648] Sayer, A. (1992) Method in Social Science: A Realist Approach. 2nd edn. London: Routledge.

[649] Sayer, D. (1991) Capitalism and Modernity: An Excursus on Marx and Weber. London: Routledge.

[650] Sayers, S. (1989) 'Knowledge as Social Phenomenon'. Radical Philosophy 52: 34-37. 
[651] Schmidt, E. P. (ed.) (1937) Man and Society. New York: Prentice Hall.

[652] Schroeder, R. (1 992) Max Weber and the Sociology of Culture. London: Sage.

[653] Schutz, A. (1972) The Phenomenology of the Social World. Originally published in 1932. Translated by Walsh, G. and Lehnert, F. Introduction by Walsh, G. London: Heinemann.

[654] Schutz, A. (1979) 'Concept and Theory Formation in the Social Sciences'. In Bynner, J. and Stribley, K. (eds).

[655] Schwartz, J. (1990) 'Antihumanism in the Humanities'. Public Interest 99: 29-44.

[656] Sciulli, D. (1985) 'The Practical Groundwork of Critical Theory: Bringing Parsons to Habermas (and vice versa)'. In Alexander, J. (ed.).

[657] Segal, L. (1987) Is the Future Female? Troubled Thoughts on Contemporary Feminism. London: Virago.

[658] Seidman, S. (2001) Contested Knowledge: Social Theory in the Postmodern Era. Oxford: Blackwell. $2^{\text {nd }}$ Edition.

[659] Seidman, S. (ed.) (1994) The Postmodern Turn: New Perspectives on Social Theory. Cambridge: Cambridge University Press.

[660] Seidman, S. and Wagner, D. (eds) (1992) Postmodernism and Social Theory. Oxford: Blackwell.

[661] Sharrock, W. and Anderson, B. (1986) The Ethnomethodologists. London: Tavistock.

[662] Sharrock, W. and Anderson, B. (1991) 'Epistemology: Professional Scepticism'. In Button, G. (ed.).

[663] Shibutani, T. (ed.) (1973) Human Natureand Collective Behaviour: Books in Honor of Herbert Blumer. New Brunswick, NJ: Transaction.

[664] Shilling, C. (1993) The Body and Social Theory. London: Sage.

[665] Shott, S. (1987) 'Emotion and Social Life: A Symbolic Interactionist Analysis'. Reprinted in Plummer, K. (ed.) (1991 b).

[666] Shotter, J. (1993) Cultural Politics of Everyday Life: Social Constructionism, Rhetoric and Knowing of the Third Kind. Buckingham: Open University Press.

[667] Sibeon, R. (2004) Rethinking Social Theory. London: Sage.

[668] Simons, H. W. and Billig, M. (eds) (1994) After Postmodernism: Reconstructing Ideology Critique. London: Sage.

[669] Simons, J. (1995) Foucault and the Political. London: Routledge.

[670] Singer, P. (1983) Hegel. Oxford: Oxford University Press.

[671] Skinner, Q. (ed.) (1991) The Return of Grand Theory in the Human Sciences. Cambridge: Cambridge University Press.

[672] Slater, D. (1994) 'Exploring Other Zones of the Postmodern: Problems of Ethnocentrism and Difference across the North-South Divide'. In Rattansi, A. and Westwood, S. (eds).

[673] Smart, B. (1990) 'Modernity, Postmodernity and the Present'. In Turner, B. S. (ed.). 
[674] Smart B (2002) `Accounting for Anxiety: Economic and Cultural Imperatives Transforming University Life', in D Hayes and R Wynyard (eds) The McDonaldization of Higher Education, London, Bergin and Garvey.

[675] Smart, B. (2003) Economy, Culture and Society: A Sociological Critique of NeoLiberalism, Buckingham, Open University Press.

[676] Smith, C. W. (1983) 'A Case Study of Structuration: The Pure-Bred Beef Business'. Journal for the Theory of Social Behaviour 13: 4-1 8.

[677] Smith, D. E. (1 974) 'Theorizing as Ideology'. In Turner, R. (ed.).

[678] Smith, D. E. (1 987) The Everyday World as Problematic: A Feminist Sociology. Milton Keynes: Open University Press.

[679] Smith, D. E. (1993) Texts, Facts and Femininity: Exploring the Relations of Ruling. London: Routledge.

[680] Smith, N. (1993) 'Putting Practice into Theory: A Review Essay'. Radical Philosophy 63: 4244 .

[681] Soper, K. (1993) 'Productive Contradictions'. In Ramazanoglu, C. (ed.).

[682] Spencer, H. (1969) Herbert Spencer. Edited with an introduction by Low-Beer, A. London: Macmillan.

[683] Spender, D. (1980) Man-Made Language. London: Routledge \& Kegan Paul.

[684] Spender, D. (ed.) (1983) Feminist Theorists: Three Centuries of Women's Intellectual Traditions. London: Women's Press.

[685] Spender, D. (1983) Women of Ideas (and what men have done to them). London: Ark. [686] Spybey, T. (1995) Globalization and World Society. Cambridge: Polity.

[687] Stinchcombe, A. L. (1990) 'Milieu and Structure Updated: A Critique of the Theory of Structuration'. In Clark, J., Modgil, C. and Modgil, S. (eds).

[688] Stones, R. (2002) 'Social Theory, Documentary Film and Distant Others: Simplicity and Subversion in The Good Woman of Bangkok', European Journal of Cultural Studies 5(2): 217-237

[689] Stones, R. (2005) Structuration Theory, London: Palgrave Macmillan.

[690] Stones, R. (2006) 'Rights, Social Theory and Political Philosophy: A Framework for Case Study Research', in L. Morris (ed.) Rights: Sociological Perspectives. London: Routledge, pp. 133-51.

[691] Strasser, S. (1985) Understanding and Explanation: Basic Ideas Concerning the Humanity of the Human Sciences. Pittsburgh, Pa: Duquesne University Press.

[692] Strauss, A. (1978) Negotiations, Varieties, Contexts, Processes and Social Order. San Francisco: Jossey Bass.

[693] Strauss, A. (1982) 'Interorganizational Negotiation'. Reprinted in Plummer, K. (ed.) (1991b).

[694] Stryker, S. (1980) Symbolic Interactionism: A Social Structural Version. Menlo Park, Calif.: BenjaminICummings.

[695] Sudnow, D. (ed.) (1972) Studies in Social Interaction. New York: Free Press. 
[696] Sydie, R. (1987) Natural Women, Cultured Men: A Feminist Perspective on Sociological Theory. Milton Keynes: Open University Press.

[697] Tannen, D. (ed.) (1993) Gender and Conversational Interaction. New York: Oxford University Press.

[698] Taylor, C. (1981) 'Understanding in Human Science'. Review of Metaphysics 34: 25-38.

[699] Taylor, C. and Montefiore, A. (1980) 'From an Analytical Perspective'. An introductory essay in Kortian, G.

[700] Thomas, W. I. and Thomas, D. S. (1928) The Child in America: Behavior Problems and Programs. New York: Knopf.

[701] Thomas, W. I. and Znaniecki, F. (1918-19) The Polish Peasant in Europe and America. 5 volumes. Boston, Mass.: Badger.

[702] Thompson, J. B. (1981) Critical Hermeneutics: A Study in the Thought of Paul Ricoeur and Jiirgen Habermas. Cambridge: Cambridge University Press.

[703] Thompson, J. B. (1 984) Studies in the Theory of Ideology. Cambridge: Polity.

[704] Thorne, B., Kramerae, C. and Henley, N. (eds) (1983) Language, Gender and Society. Rowley, Mass.: Newbury House.

[705] Tiryakian, E. A. (1979) 'Emile Durkheim'. In Bottomore, T. and Nisbet, R. (eds). Tong, R. (1989) Feminist Thought: A Comprehensive Introduction. London: Unwin Hyman.

[706] Toynbee, A. (1954) A Study of History: Volume 9. London: Oxford University Press.

[707] Turner, B. S. (1 98 1) For Weber: Essays on the Sociology of Fate. London: Routledge \& Kegan Paul.

[708] Turner, B. S. (ed.) (1990) Theories of Modernity and Postmodernity. London: Sage.

[709] Turner, B. S. and Robertson, R. (1991) 'How to Read Parsons'. In Robertson, R. and Turner, B. S. (eds).

[710] Turner, J. H. (1974) 'Parsons as a Symbolic Interactionist: A Comparison of Action and Interaction Theory'. Reprinted in Plummer, K. (ed.) (1991a).

[711] Turner, R. (1974a) 'Words, Utterances and Activities'. In Turner, R. (ed.).

[712] Turner, R. (ed.) (1974b) Ethnomethodology. Harmondsworth: Penguin.

[713] Vance, C. S. (ed.) (1992) Pleasure and Danger: Exploring Female Sexuality. London: Pandora.

[714] Visker, R. (1995) Michel Foucault: Genealogy as Critique. Translated by Turner, C. London: Verso.

[715] Wacquant, L. (1992) 'The Structure and Logic of Bourdieu's Sociology'. In Bourdieu, P. and Wacquant, L. (Eds.)

[716] Wacquant, L. (1993) 'Bourdieu in America: Notes on the Transatlantic Importation of Social Theory'. In Calhoun, C., LiPuma, E. and Postone, M. (eds).

[717] Walby, S. (1986) Patriarchy at Work: Patriarchal and Capitalist Relations in Employment. Cambridge: Polity.

[718] Walby, S. (1990) Theorizing Patriarchy. Cambridge: Polity. 
[719] Wallerstein, I. (1990) 'World-Systems Analysis'. In Giddens, A. and Turner, J. (eds).

[720] Ward, G. (2003) Postmodernism. London: Hodder Headline

[721] Warren, M. (1992) 'Max Weber's Nietzschean Conception of Power'. History of the Human Sciences 5(3) : 19-3 7.

[722] Weber, M. (1949) The Methodology of the Social Sciences. Edited by Shils, E. and Finch, H. Glencoe, Ill.: Free Press.

[723] Weber, M. (1985) The Protestant Ethic and the Spirit of Capitalism. Originally published in 1930. London: Unwin.

[724] Webster, F. (1 995) Theories of the Information Society. London: Routledge.

[725] Weedon, C. (1987) Feminist Practice and Poststructuralist Theory. Oxford: Blackwell.

[726] Weinbaum, B. (1978) The Curious Courtship of Women's Liberation and Socialism. Boston, Mass.: South End Press.

[727] Weinstein, D. and Weinstein, M. (1991) 'Georg Simmel: Sociological Fliineur Bricoleur'. In Featherstone, M. (ed.).

[728] West, C. and Zimmerman, D. H. (1983) 'Small Insults: A Study of Interruptions in Cross-Sex Conversations with Unacquainted Persons'. In Thorne, B., Kramerae, C. and Henley, N. (eds).

[729] White, S. (1990) The Recent Work of Jiirgen Habermas: Reason, Justice and Modernity. Cambridge: Cambridge University Press.

[730] Wieder, D. L. (1 974) 'On Meaning by Rule'. In Douglas, J. D. (ed.). Wiggershaus, R. (1995) The Frankfurt School: Its History, Theories and Political Significance. Translated by Robertson, M. Cambridge: Polity.

[731] Wilkinson, R. (ed) (2005) The Global Governance Reader, London, Routledge.

[732] Williams, M. and May, T. (1996) Introduction to the Philosophy of Social Research. London: UCL Press.

[733] Williams, Raymond (1 961) Culture and Society: 1 780-1 950. Harmondsworth: Penguin.

[734] Williams, Robin (1980) 'Goffman's Sociology of Talk'. In Ditton, J. (ed.).

[735] Williams, Robin (1988) 'Understanding Goffman's Methods'. In Drew, P. and Wootton, A. (eds).

[736] Wilson, B. (ed.) (1970) Rationality. Oxford: Blackwell.

[737] Wilson, E. (1990) 'Psychoanalysis: Psychic Law and Order?' In Lovell, T. (ed.).

[738] Winch, P. (1990) The Idea of a Social Science and its Relation to Philosophy. $2^{\text {nd }}$ edn. Originally published in 1958. London: Routledge.

[739] Wolff, K. H. (1979) 'Phenomenology and Sociology'. In Bottomore, T. and Nisbet, R. (eds).

[740] Wolffensperger, J. (1991) 'Engendered Structure: Giddens and the Conceptualisation of Gender'. In Davis, K., Leijenaar, M. and Oldersma, J. (eds). 
[741] Wollstonecraft, M. (1989) A Vindication of the Rights of Women. Originally published in 1792. Buffalo, NY: Prometheus.

[742] Wright, E. 0. (1989) 'Models of Historical Trajectory: An Assessment of Giddens's Critique of Marxism'. In Held, D. and Thompson, J. B. (eds).

[743] Zimmerman, D. H. and Wieder, D. L. (1974) 'Ethnomethodology and the Problem of Order: Comments on Denzin'. In Douglas, J. D. (ed.).

[744] Zollschan, G. K. and Hirsch, W. (eds) (1976) Social Change: Explorations, Diagnoses and Conjectures. New York: Wiley. 